\section{Pacific Northwest}

National Laboratory

Operated by Battelle for the

U.S. Department of Energy

\title{
Health Impacts from Acute Radiation Exposure
}

D.J. Strom

September 2003

Prepared for the U.S. Department of Energy under Contract DE-AC06-76RL01830 


\title{
DISCLAIMER
}

This report was prepared as an account of work sponsored by an agency of the United States Government. Neither the United States Government nor any agency thereof, nor Battelle Memorial Institute, nor any of their employees, makes any warranty, express or implied, or assumes any legal liability or responsibility for the accuracy, completeness, or usefulness of any information, apparatus, product, or process disclosed, or represents that its use would not infringe privately owned rights. Reference herein to any specific commercial product, process, or service by trade name, trademark, manufacturer, or otherwise does not necessarily constitute or imply its endorsement, recommendation, or favoring by the United States Government or any agency thereof, or Battelle Memorial Institute. The views and opinions of authors expressed herein do not necessarily state or reflect those of the United States Government or any agency thereof.

\author{
PACIFIC NORTHWEST NATIONAL LABORATORY \\ operated by \\ BATTELLE \\ for the \\ UNITED STATES DEPARTMENT OF ENERGY \\ under Contract DE-AC06-76RLO 1830
}


PNNL-14424

UC-610

\title{
Health Impacts from Acute Radiation Exposure
}

\author{
D. J. Strom
}

September 2003

Prepared for the Office of Security Affairs

U.S. Department of Energy

under Contract DE-AC06-76RLO 1830

Pacific Northwest National Laboratory

Richland, Washington 99352 


\section{Executive Summary}

Acute radiation exposure refers to the delivery of high doses of radiation in periods of time on the order of days or less. Acute radiation exposure of human beings can occur through accidents, criminal activity, or acts of war. This report reviews the expected health impacts of exposures to people delivered at high dose rates. Two major variables needed to predict outcomes in people are the amount of radiation dose and its distribution in time, that is, dose rate and fractionation. Health impacts are categorized by time of appearance after irradiation as early and late effects.

Early effects are termed deterministic, and their severity is an increasing function of dose and dose rate, with a dose threshold below which symptoms do not appear. Health impacts of relatively uniform irradiation of the whole body include three acute radiation syndromes, namely, the hematopoietic (bone marrow), gastrointestinal (GI), and cerebrovascular (CV) syndromes, with thresholds of about 2, 10, and 50 grays (Gy; 200, 1,000, and 50,000 rads). The dose that is expected to produce $50 \%$ mortality from the bone marrow syndrome in a population within 60 days, the $L D_{50-60}$, is over $4 \mathrm{~Gy}$ (400 rads) if minimal medical treatment is provided, and over 6 Gy (600 rads) if supportive medical treatment is provided. While the $L D_{50}$ values for the GI and CV syndromes are higher, those doses invariably cause bone marrow fatality. Other syndromes that may cause fatality result from non-uniform irradiation. These are the cutaneous syndrome, in which the skin is heavily irradiated by beta irradiation, and the pulmonary syndrome, in which inhalation of beta-emitting or alpha-emitting radioactive material cause damage to the skin or lungs. Other deterministic effects include developmental abnormalities in the embryo, the fetus, or in growing children, such as mental retardation and thyroid disease. Loss of pregnancy, permanent or temporary sterility or impaired fertility, and cataracts (opacification of the crystalline lens of the eye) are also known effects. As doses to skin increase, erythema (skin reddening), desquamation (blistering), ulceration, and necrosis (tissue death) can also occur. Untreated ulceration or necrosis can also lead to death.

If people survive the early, deterministic effects, they still bear some risk of late effects such as cancer and leukemia; some non-cancer conditions such as heart disease, stroke, digestive diseases, and respiratory diseases; and heritable ill-health. Cancers and heritable ill-health (formerly called genetic effects) occur in a population with a frequency that is an increasing function of dose, usually without threshold. As an illustration of late effects, in the latest (October 2003) followup of the Japanese nuclear bomb survivors, about 5\% of 9,335 solid cancer deaths and $0.8 \%$ of 31,881 noncancer deaths in the survivor population are attributable to radiation exposures from the nuclear detonations.

Many factors affect the radiosensitivity of people, including dose, dose rate, dose fractionation, the penetrating or non-penetrating nature of the radiation that varies inversely with the radiation's linear energy transfer ( $L E T)$. In addition to these factors, medical care, uniformity of irradiation, age at exposure, sex, genetic susceptibility, adaptive response (if any), trauma, chemical exposure, nutritional state, and state of infection all influence health impacts. 


\section{Contents}

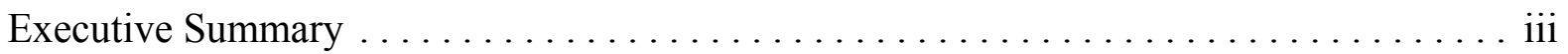

Contents $\ldots \ldots \ldots \ldots \ldots \ldots \ldots \ldots \ldots \ldots \ldots \ldots \ldots \ldots \ldots$ iv

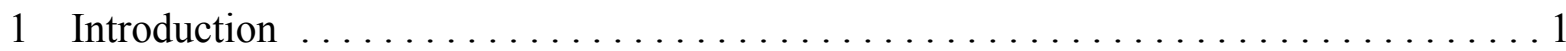

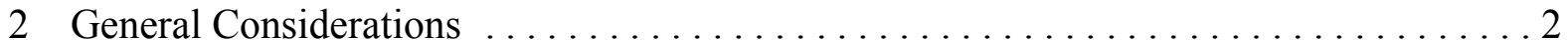

2.1 Radiation Dose, Dose Rate, Fractionation, and Linear Energy Transfer $($ LET $)$. . . . . 2

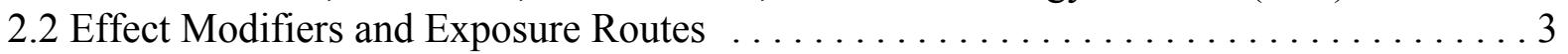

2.3 Three Categories of Radiation Effects in Human Beings: Somatic, Heritable Genetic,

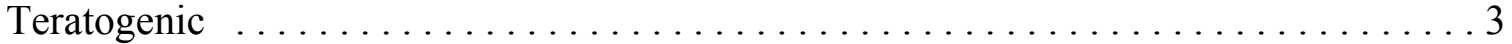

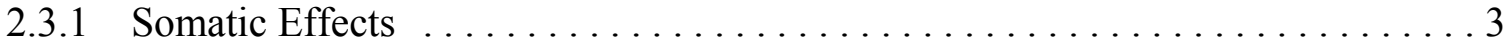

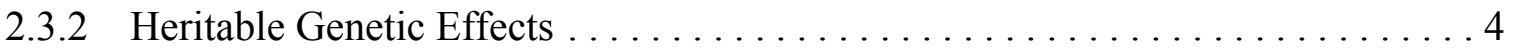

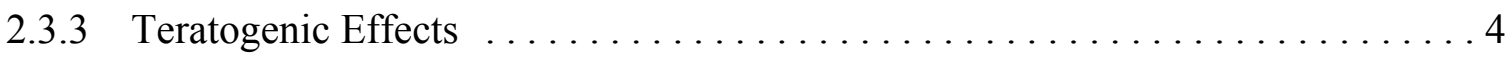

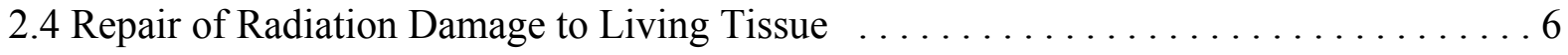

2.5 Somatic Effects (Effects to the Body of the Exposed Individual) $\ldots \ldots \ldots \ldots \ldots \ldots 6$

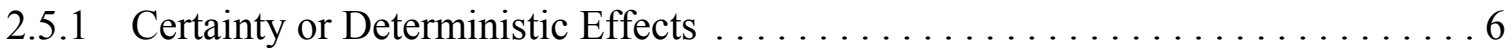

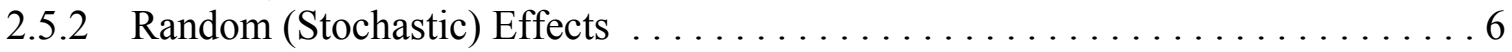

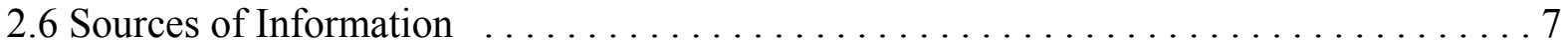

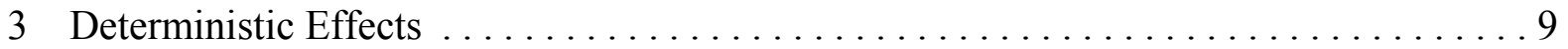

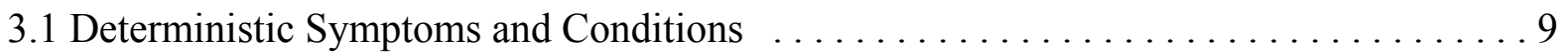

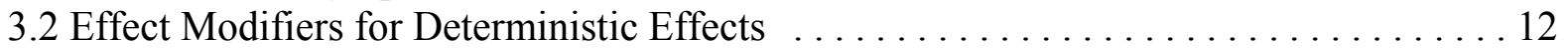

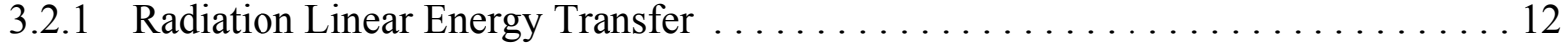

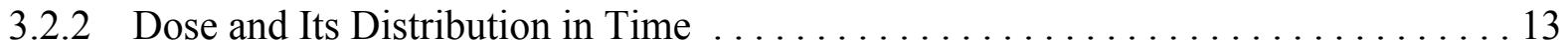

3.2.3 Kind and Degree of Medical Care .......................... 14

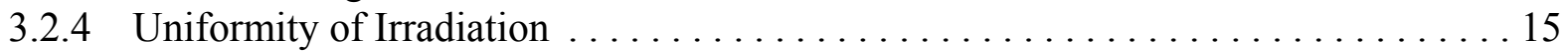

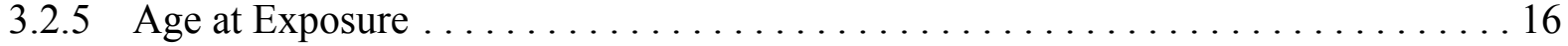

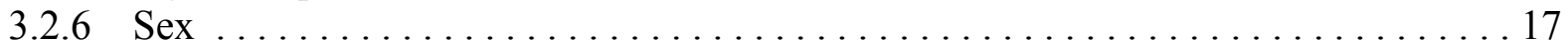

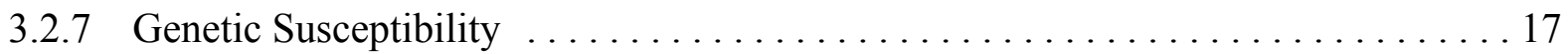

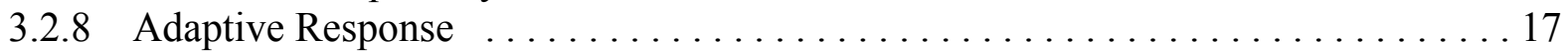

3.2.9 Other Effect Modifiers: Cell Cycle, Trauma, Chemical Exposure, Nutrition, Infection

4 Death as a Result of Deterministic Health Effects of Radiation ............... 19

4.1 Dose-Response Relationships (DRRs) for Hematopoietic Syndrome Mortality . . . . . . 20

4.2 Gastorintestinal Syndrome . . . . . . . . . . . . . . . . . . . . . . . . 23

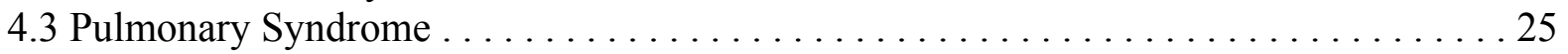

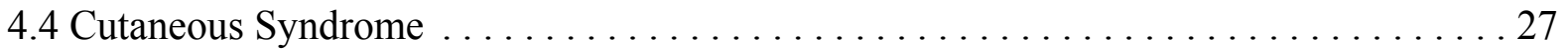

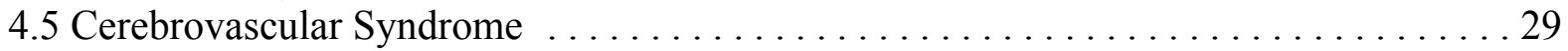

4.6 Other Deterministic Health Effects .............................. 30 
4.6.1 Teratogenesis . ..................................... 30

4.6.2 Late Noncancer Effects: Heart Disease, Stroke, Digestive Diseases, and

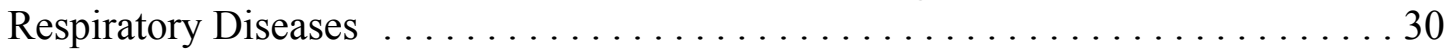

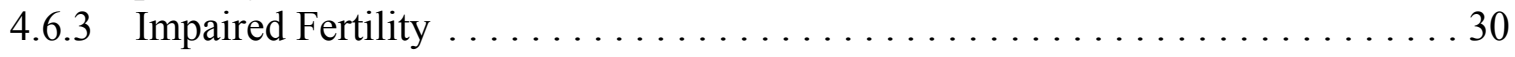

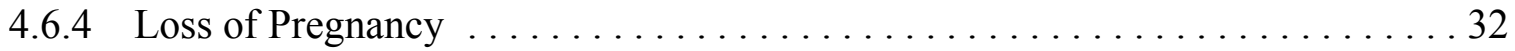

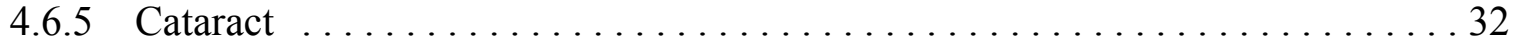

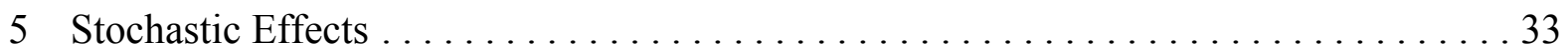

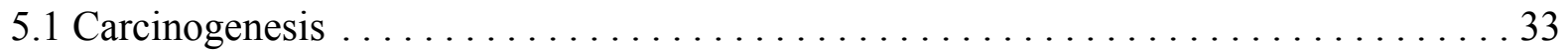

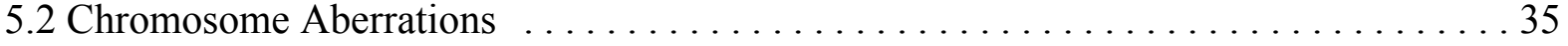

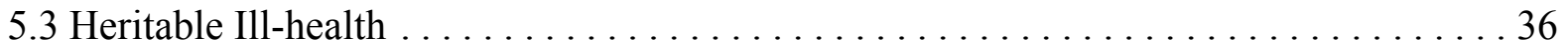

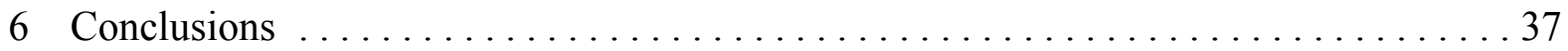

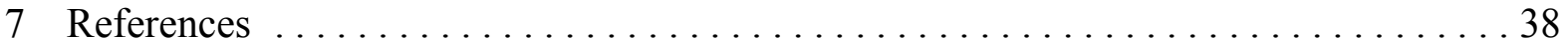




\section{Introduction}

This document is a review of the state of the art for estimating early and late health impacts from high dose, acute radiation exposure. There are many technical factors that must be considered to understand the complex nature of exposure to ionizing radiation.

Effects of acute radiation exposures were observed soon after x-rays were discovered in 1895 . Subsequently, they have been observed and studies in human populations including workers, medical patients, and members of the public, including the survivors of the 1945 nuclear bombings in Japan.

Radiation has been described as a double-edged sword. On the one hand, radiation itself is a useful tool for research; medical diagnosis and therapy; materials processing; non-destructive testing; sterilization of instruments, pharmaceuticals, food, and mail; and inhibition of sprouting. There are also beneficial technologies that produce radiation and/or radioactive materials as byproducts or concentrate radioactive materials include nuclear propulsion and electric generation; and gas, oil and mineral extraction. Other beneficial technologies enhance concentrations of radioactive materials (buildings concentrate radon) or expose people to radiation levels above background (air travel).

On the other hand, radiation exposures, especially at high levels, can lead to increased frequencies or severities of various adverse health effects.

The goal of this review is to present dose response relationships (DRRs) to use in estimation of potential impacts from events that deliver acute radiation doses to people. This paper does not address the effects of radiation doses delivered over long periods of time (months or years). 


\section{General Considerations}

Irradiation is the process of exposing something to radiation. Irradiation can occur to all or part of the body, and can be relatively uniform or highly non-uniform. Radiation from sources outside of the body, including radioactive materials on the skin, produces external irradiation, while radioactive materials taken into the body produce internal irradiation. ${ }^{1}$

\subsection{Radiation Dose, Dose Rate, Fractionation, and Linear Energy Transfer $(L E T)$}

In the infancy of radiological science, there was a struggle to devise ways of measuring the "quantity of radiation," often with the goal of making images on film. Today we specify "quantity of radiation" as absorbed dose, measured in grays (unit symbol: Gy), where 1 Gy is one joule of ionizing radiation energy deposited in one kilogram of absorber (International Commission on Radiation Units and Measurements (ICRU) 1998). ${ }^{2}$ Unless otherwise specified, "dose" in this document refers to absorbed dose.

One historically important measure of "quantity of radiation" is ionization in air, traditionally measured in roentgens (unit symbol: R) and termed "exposure." In this specialized radiological sense, exposure "free in air" (FIA) ${ }^{3}$ can be related to absorbed dose by $1 \mathrm{R}=0.00876$ Gy or $1 \mathrm{R}$ $=8.76 \mathrm{mGy}$. The radiological quantity "exposure" is limited to external irradiation by x-ray or gamma radiation sources. Exposure can only be specified and measured in air. Exposure cannot be used for neutrons or charged particles such as beta particles or alpha particles, so it cannot be used for intakes of radioactive materials.

In addition to "quantity of radiation," many other properties of radiation affect the biological response of living organisms. The rate at which absorbed dose is delivered is termed absorbed dose rate, and is measured in grays per hour (unit symbol: Gy/h). Radiation tends to produce the maximum biological damage per unit absorbed dose if the dose is delivered in a very short time, seconds or minutes. Such a dose would be delivered at a very high absorbed dose rate. If irradiation is protracted enough to permit some repair during irradiation, that is, if the absorbed dose rate is lower, then there is less biological damage per unit absorbed dose. Alternatively, if a given dose is delivered in fractions separated in time by hours or days, there is generally less

${ }^{1}$ External irradiation is popularly termed "external exposure," while internal irradiation is popularly termed "internal exposure." Exposure to radioactive materials, and subsequent irradiation after those materials have been taken into the body, are cause and effect, so the use of the word "exposure" to mean irradiation, as in "internal exposure," causes confusion. (exactly).

${ }^{2}$ The traditional unit of absorbed dose is the rad (unit symbol: $\mathrm{rad}$ ), $1 \mathrm{rad}=0.01 \mathrm{~Gy}$

${ }^{3}$ Free-in-air means that there are no nearby objects or persons to scatter radiation back to the detector and increase the reading. 
damage per unit absorbed dose.

Different kinds of charged particles produce different amounts of ionization as they traverse matter. Charged particle radiations, such as beta, proton, or alpha particle radiation, directly ionize atoms and molecules. Uncharged particle radiations, such as x and gamma radiation and neutrons, set in motion charged particles, called secondary radiation, in the matter with which they interact.

Alpha particles are densely ionizing, as are high-speed "knock-on" protons produced by fast neutron collisions with hydrogen nuclei. Beta particles and the electrons set in motion by $\mathrm{x}$ and gamma radiation are sparsely ionizing. Densely ionizing radiation is far less penetrating in tissue than sparsely ionizing radiation. The penetrating power of a particular kind of radiation, generally specified in tissue, is inversely related to the linear energy transfer (LET) of charged particles, or the $L E T$ of the secondary charged particles liberated by uncharged particles.

Thus, radiation dose, dose rate or duration of irradiation, dose fractionation, and LET must be specified to understand health effects.

The term $L D_{50}$ refers to the lethal dose that kills $50 \%$ of those exposed to that dose. Sometimes one sees $L D_{50-60}$, the lethal dose that kills $50 \%$ of those exposed to that dose within 60 days. The $L D_{50-60}$ is appropriate for the bone marrow (hematopoietic) syndrome, discussed below.

\subsection{Effect Modifiers and Exposure Routes}

Once dose, dose rate, fractionation, and $L E T$ are understood, other effect modifiers that must be considered. These include kind and degree of medical care, uniformity of irradiation, age at exposure, sex, genetic susceptibility, adaptive response, and other effect modifiers such as position in the cell cycle, trauma, chemical exposure, and infection.

Exposure routes include external irradiation, and irradiation following inhalation or ingestion of radioactive materials, and dermal contact with radioactive materials.

2.3 Three Categories of Radiation Effects in Human Beings: Somatic, Heritable Genetic, Teratogenic

We divide the health effects of ionizing radiation into three categories.

\subsubsection{Somatic Effects}

Somatic effects are effects occurring in the exposed person, that, in turn, may be divided into two temporal classes.

\subsubsection{Early or Prompt Health Effects}


Early or prompt effects are observable soon after a large or acute dose (for example, 1 Gy or more to the whole body within a few hours), but include the various radiation syndromes that may extend for months.

\subsubsection{Late or Delayed Health Effects}

Late or delayed effects, such as cancer, cataract, cardiovascular disease, and radiodermatitis may occur years after exposure to radiation.

\subsubsection{Heritable Genetic Effects}

Heritable genetic effects are abnormalities that may occur in the future children of exposed individuals (mother or father) and in subsequent generations.

\subsubsection{Teratogenic Effects}

Teratogenic effects are developmental effects that may be observed in children who were exposed during the fetal and embryonic stages of development (that is, effects to unborn children who were exposed in the womb). One can argue that these are somatic effects, but they are usually discussed separately.

Table 1 is a chart of radiation doses and effects from tiny, trivial doses to doses that literally result in heating. Following the deliberate contamination of mail with anthrax spores in the fall of 2001, mail destined for selected U.S. Government offices began to be irradiated using electron beams (Castle et al. 2003). The dose needed for reasonable assurance of killing virtually all anthrax spores is higher than many doses routinely used in industry. 
Table 1. Doses, Effects, and Sources on a Logarithmic Dose Scale

\begin{tabular}{|c|c|c|c|}
\hline $\begin{array}{c}\text { Dose }^{\mathrm{a}} \\
(\mathrm{Sv} \text { or Gy) }\end{array}$ & Death? & Effect of Acute Uniform Dose & Source of Dose of This Magnitude \\
\hline$>42,000$ & yes & $\begin{array}{l}>10^{\circ} \mathrm{C} \text { temperature rise (water); } \\
>20^{\circ} \mathrm{C} \text { temperature rise (paper) }\end{array}$ & $\begin{array}{l}\text { Mail irradiation for biological } \\
\text { sterilization of spores }\end{array}$ \\
\hline 4,184 & yes & $1^{\circ} \mathrm{C}$ temperature rise in water & $\begin{array}{l}\text { Industrial processes, medical } \\
\text { sterilizers }\end{array}$ \\
\hline 1,000 & yes & (bottom end of food irradiation scale) & $\begin{array}{l}\text { Food irradiation, medical } \\
\text { sterilizers }\end{array}$ \\
\hline 300 & yes & & \\
\hline 100 & yes & $\begin{array}{l}\text { "prompt, immediate incapacitation" -- } \\
\text { U.S. Army }\end{array}$ & $1 \mathrm{~km}$ from neutron bomb \\
\hline 30 & yes & $\begin{array}{l}\text { 60-90 Gy: tumoricidal dose; cerebro- } \\
\text { vascular syndrome; desquamation }\end{array}$ & $\begin{array}{l}\text { criticality or severe accident; } \\
\text { deliberate radiation therapy }\end{array}$ \\
\hline 10 & yes & $\begin{array}{l}\text { gastrointestinal syndrome; marrow } \\
\text { ablation; erythema, epilation, sterility }\end{array}$ & $\begin{array}{l}12 \text { Gy in leukemia therapy; max } \\
\text { dose to Chernobyl fireman }\end{array}$ \\
\hline 3 & $?$ & $\begin{array}{l}50 \% \text { die } 60 \text { days no medical care; } \\
\text { bone marrow (hematopoietic) syndrome }\end{array}$ & $\begin{array}{l}\text { Japanese A-bomb survivors; } \\
\text { fluoroscopy in cardiac catheterization }\end{array}$ \\
\hline 1 & & mild clinical symptoms in some & $\begin{array}{l}\text { teratogenesis in Japanese A- } \\
\text { bomb survivors unborn children }\end{array}$ \\
\hline 0.3 & & $\begin{array}{l}\text { no clinical symptoms; } \\
\text { chromosome aberrations }\end{array}$ & $\begin{array}{l}\text { planned special exposure; lots } \\
\text { of x-rays on same day }\end{array}$ \\
\hline 0.1 & & $\begin{array}{l}\text { increased risk of cancer (?) and } \\
\text { heritable ill-health (?) }\end{array}$ & $\begin{array}{l}\text { planned special exposure; some } \\
\text { nuclear medicine procedures }\end{array}$ \\
\hline 0.03 & & no observed effects in humans & $\begin{array}{l}0.05 \mathrm{~Sv} / \mathrm{y} \text { occupational limit; } \\
\text { bone scan, several x-rays }\end{array}$ \\
\hline 0.01 & & no observed effects in humans & $\begin{array}{l}\text { dose/y to air crew; partial body } \\
\text { dose from } 1 \text { lumbar spine x-ray }\end{array}$ \\
\hline 0.003 & & no observed effects in humans & $\begin{array}{l}1 \text { dental x-ray; annual rad. } \\
\text { worker; annual background }\end{array}$ \\
\hline 0.001 & & no observed effects in humans & $\begin{array}{l}\text { av. medical }+ \text { dental dose }= \\
0.0005 / y)\end{array}$ \\
\hline 0.0003 & & no observed effects in humans & $\begin{array}{l}\text { partial body dose from chest } \mathrm{x} \text { - } \\
\text { ray }\end{array}$ \\
\hline 0.0001 & & no observed effects in humans & flight from Seattle to Tokyo \\
\hline
\end{tabular}

${ }^{a}$ Doses are in Gy above about 1; in Sv for all radiation or Gy for low-LET below 1. 


\subsection{Repair of Radiation Damage to Living Tissue}

Radiation deposits energy in living tissue, causing ionizations, which in turn create chemical changes within individual cells. These chemical changes may result in damage to the cells. Some, often most, of the damage can be repaired by cells if doses are low, such as received in occupational settings. The repair of damaged cells proceeds normally if the dose isn't too high. Sunburn and cuts are familiar examples of cell damage that can be repaired if the initial damage is not too great.

However, at very high doses of radiation delivered at high dose rates, the repair mechanisms themselves may be damaged or they may be overwhelmed. In these cases, severe injury and even death may occur.

Important concepts include the repair and misrepair of damage to DNA. At low dose rates, repair may keep up with damage. At higher dose rates, repair by normal repair mechanisms may fall behind, and other, lower-fidelity repair mechanisms may be induced, resulting in a greater proportion of misrepair.

2.5 Somatic Effects (Effects to the Body of the Exposed Individual)

Somatic effects are further divided into two groups, deterministic effects and stochastic effects.

\subsubsection{Certainty or Deterministic Effects}

Health effects whose severity depends on radiation dose (usually with a threshold) and dose rate are called deterministic effects ${ }^{4}$. None ${ }^{5}$ of the deterministic effects is seen below $0.2 \mathrm{~Sv}$ or 0.2 Gy low-LET radiation.

\subsubsection{Random (Stochastic) Effects}

Health effects whose frequency of occurrence in a population (rather than whose severity) depends on radiation dose and dose rate, such as cancer and heritable ill-health, are called stochastic effects. There are no "mild" cases of cancer, whether radiation-induced or not, so its frequency of occurrence in a population is of interest.

For most stochastic effects, there is probably no threshold dose.

${ }^{4}$ Deterministic effects were formerly called "non-stochastic" effects.

${ }^{5}$ In utero irradiation of the unborn causes mental retardation whose severity, as well as frequency, is related to dose. Such mental retardation may not have a threshold. 
None of the stochastic effects seen at late times after irradiation is unique to radiation - all can occur in the absence of radiation exposure.

Examples of stochastic effects include cancer, non-cancer effects, heritable ill-health (altered genes in germ cells prior to procreation, also known as genetic effects), and perhaps some teratogenic effects.

\subsection{Sources of Information}

A great deal of information is available on health effects of ionizing radiation.

The National Academy of Sciences has published several reports on the biological effects of ionizing radiation (BEIR), focusing primarily on low-LET radiation (National Research Council 1990) or on radon (Committee on the Biological Effects of Ionizing Radiation (BEIR VI) 1998) or radon and other alpha emitters (Committee on the Biological Effects of Ionizing Radiation (BEIR VI) 1998; National Research Council 1988).

The United Nations Scientific Committee on the Effects of Atomic Radiation (UNSCEAR) has published reports on sources and effects, with annexes focusing on high dose effects (UNSCEAR 1993), adaptive response (Annex B) (UNSCEAR 1994), hereditary effects (Annex G) (UNSCEAR 1993) and (UNSCEAR 2002), and cancer (most reports).

The National Council on Radiation Protection and Measurements (NCRP) has recently reviewed low-dose cancer risks (NCRP 2001a; NCRP 1997), and provided a series of studies of high dose effects in the context of space travel (NCRP 2002; NCRP 2001b; NCRP 1989).

The International Commission on Radiological Protection (ICRP) has reviewed high-dose effects in the context of medical irradiation (ICRP 2003; ICRP 2002b; ICRP 2002a; ICRP 2000b; ICRP 2000a), and has reviewed prenatal irradiation (ICRP 2003).

The U.S. Nuclear Regulatory Commission (NRC) has undertaken extensive studies of health effects in support of its regulatory functions (USNRC 1989; USNRC 1990; USNRC 1991; USNRC 1993; Evans, Moeller, and Cooper 1985; Evans et al. 1993; Haskin et al. 1997a; Haskin et al. 1997b; Little et al. 1997a; Little et al. 1997b).

Two general textbooks stand out (Hall 2000; Mettler and Moseley, Jr. 1985), and there are available on the World Wide Web two military medicine textbooks that contain treatment options (Walker et al. 1989; North Atlantic Treaty Organization 1996). In particular, the NATO Field Manual contains nine specific treatment regimes as a function of dose, and covers decontamination (http://www.vnh.org/MedAspNBCDef/toc.htm ).

Concerning treatment, in March, 2003, the Department of Health and Human Services, Centers for Disease Control (CDC) published an "Acute Radiation Syndrome Fact Sheet for Physicians" (http://www.cdc.gov/nceh/radiation/factsheets/AcuteRadSyndrome.pdf) that has specifics and a 
good readable summary of all of the radiation syndromes except pulmonary. CDC also has casualty management documents for dispersal of radioactive materials and nuclear detonations (http://www.bt.cdc.gov/radiation/pdf/casualtiesradioactive.pdf and http://www.bt.cdc.gov/radiation/pdf/casualtiesdetonation.pdf ).

An excellent handbook was published in hardcopy and on the Internet in April of 2003 by the U.S. Armed Forces (Military Medical Operations, Armed Forces Radiobiology Research Institute 2003).

Baylor College of Medicine has a Disaster Preparedness for Radiation Accidents site (http://radefx.bcm.tmc.edu/ionizing/ionizing.htm\#Disaster ) with many dose-response entries.

It must be emphasized that those interested must download, print, and study these resources before there is any urgent need for them, since there may be no electricity and no access to the Internet if there is a disaster involving high doses of radiation. 


\section{Deterministic Effects}

Deterministic effects may occur at a variety of doses and at a variety of times after (and perhaps during) irradiation. Twenty symptoms and conditions are discussed below. In addition, five radiation syndromes plus the prodromal syndrome are discussed in the following chapter. The syndromes are collections of symptoms and conditions that have been seen in individual human beings or animals that can result in death.

\subsection{Deterministic Symptoms and Conditions}

Deterministic symptoms and conditions observed in irradiated human populations are listed in Table 2, along with two prominent stochastic effects. The threshold doses in Table 2 are very approximate; more details on thresholds are given later in this document. Whether the significant dose-related increases in heart disease, stroke, digestive diseases, and respiratory diseases reported in Report 13 of the Life Span Study are stochastic or deterministic effects remains to be determined (Preston et al. 2003). 
Table 2. High dose effects: Symptoms and conditions observed in humans (various sources)

\begin{tabular}{|c|c|c|}
\hline Symptom or Condition & Typical Time Frame & $\begin{array}{l}\text { Approx. } \\
\text { Threshold } \\
\text { Dose (Gy) }\end{array}$ \\
\hline anorexia (loss of appetite) & prodromal (minutes to hours) & 1 \\
\hline nausea & prodromal (minutes to hours) & 1 \\
\hline vomiting & prodromal (minutes to hours) & 1 \\
\hline fatigue & prodromal (minutes to hours) & 1 \\
\hline diarrhea or bloody diarrhea & prodromal (minutes to hours) & 2 \\
\hline brain damage, nerve damage, paralysis & minutes to hours (very high dose) & 15 \\
\hline unconsciousness & minutes to hours (very high dose) & 50 \\
\hline erythema (skin reddening) & days & 5 \\
\hline $\begin{array}{l}\text { moist or dry desquamation (skin peeling off in } \\
\text { scales) }\end{array}$ & days & 10 \\
\hline acute ulceration of skin (transepidermal injury) & days & $20-40$ \\
\hline $\begin{array}{l}\text { teratogenesis: developmental abnormalities due to } \\
\text { exposure between conception and birth, including } \\
\text { growth retardation and mental retardation }\end{array}$ & days to weeks & 0.2 \\
\hline $\begin{array}{l}\text { leukopenia (lowered white blood cell count) and } \\
\text { consequent impaired or absent immune system } \\
\text { response }\end{array}$ & days to weeks & 1 \\
\hline thyroid effects (thyroiditis, hypothyroidism) & days to months & 2 \\
\hline radiation pneumonitis & days to months & 7 \\
\hline $\begin{array}{l}\text { impaired fertility or sterility (temporary or } \\
\text { permanent) }\end{array}$ & days to weeks & 2 \\
\hline epilation (hair loss) & days to weeks & 3 \\
\hline necrosis (skin or tissue death) & days to weeks & 15 \\
\hline loss of pregnancy & days to weeks & $1(?)$ \\
\hline $\begin{array}{l}\text { slowed, poor, or no healing of highly irradiated } \\
\text { areas }\end{array}$ & weeks to months & 5 \\
\hline cataract (opacification of the lens of the eye) & weeks to months & 10 \\
\hline radiation dermatitis & months to years & 5 \\
\hline developmental abnormalities, growth retardation & months to years & $0.2(?)$ \\
\hline $\begin{array}{l}\text { heart disease, stroke, digestive diseases, } \\
\text { respiratory diseases }\end{array}$ & years & 0.5 \\
\hline cancer, leukemia & years & none \\
\hline heritable ill-health & generations & none \\
\hline
\end{tabular}


Examples of deterministic radiation effects with dose ranges are shown in Table 3 (Mettler and Moseley, Jr. 1985). The NCRP conclusions are presented in Table 4 (NCRP 1989). More quantitative dose-response figures are shown in Table 5.

Table 3. Doses required to produce deterministic effects (Mettler and Moseley 1985 pp. 172176)

\begin{tabular}{cl}
\hline Dose (Gy) & Effect \\
\hline $2-7$ & bone marrow (hematopoietic) syndrome (not always lethal) \\
$>10$ & necrosis or cell killing (local irradiation or in vitro experiments) \\
$>10$ & skin burns (beta burns) \\
$7-50$ & GI (gastrointestinal) syndrome \\
$>50$ & CVS (cerebrovascular system) syndrome (formerly central nervous \\
& system [CNS] syndrome and cardiovascular syndrome; now combined) \\
\hline
\end{tabular}

Table 4. Exposure Levels at Which Health Effects Appear in Healthy Adults (NCRP 1989)

\begin{tabular}{lc}
\hline Effects & Acute dose (Gy) \\
\hline Blood count changes & 0.50 \\
Vomiting (threshold) & 1.00 \\
Mortality (threshold) & 1.50 \\
LD50/60 (minimal supportive care) & $3.2-3.6$ \\
LD50/60 (supportive medical treatment) & $4.8-5.4$ \\
LD50/60 (autologous bone marrow or stem cell transplant) & $>5.4$ \\
\hline
\end{tabular}


Table 5. Equal-weight aggregate of elicited percentiles of $L D_{50}$ at $100 \mathrm{~Gy} / \mathrm{hr}$ versus NUREG/CR-4214, Rev. 2 values assuming minimal medical treatment. Reproduced from Table 4.1 from Haskin et al. 1997.

\begin{tabular}{|c|c|c|c|c|c|c|}
\hline & \multicolumn{3}{|c|}{$\begin{array}{l}\text { Equal-weight aggregate of } \\
\text { elicited percentiles of } L D_{50} \\
\text { (Gy) at } 100 \mathrm{~Gy} / \mathrm{hr}^{\mathrm{a}}\end{array}$} & \multicolumn{3}{|c|}{$\begin{array}{c}D_{50}(\mathrm{~Gy}) \text { from NUREG/CR- } \\
4214 \text { Rev. } 2\end{array}$} \\
\hline & $5 \%$ & $50 \%$ & $95 \%$ & Lower & Central & Upper \\
\hline Hematopoietic syndrome & 2.0 & 3.3 & 5.5 & 2.5 & 3.0 & 3.5 \\
\hline Pulmonary syndrome & 6.7 & 9.3 & 11.7 & 8 & 10 & 12 \\
\hline Gastrointestinal syndrome & 5.7 & 9.6 & 17.2 & 10 & 15 & 20 \\
\hline
\end{tabular}

\subsection{Effect Modifiers for Deterministic Effects}

Several factors may dramatically modify the effect of absorbed doses of ionizing radiation, including

- radiation $L E T$,

- dose and its distribution in time,

- uniformity of irradiation,

- age at exposure,

- sex,

- genetic susceptibility,

- adaptive response,

- kind and degree of medical care, and

- other factors.

These are discussed below.

\subsubsection{Radiation Linear Energy Transfer}

The biological consequence for a given absorbed dose varies with radiation linear energy transfer (LET). This is expressed as the relative biological effectiveness (RBE) of a given radiation relative to x-rays. Strictly speaking, $R B E$ is an outcome of a particular endpoint (e.g., a specific type of cancer) of an experiment comparing the effects of two different kinds of radiation on a particular species under particular conditions of irradiation, and is not necessarily generalizable to a different endpoint, different species, or different irradiation conditions. RBEs tend to be higher for lower doses of radiation, and tend to diminish for higher doses (above 1 Gy). Such effects have been clearly seen in human survivors of criticality accidents, and have been experimentally reproduced in burros (Thomas and Brown 1961). 
By analogy, the quality factor, $Q$, or radiation weighting factor $\left(w_{T}\right)$ that relates dose equivalent or equivalent dose, respectively, to absorbed dose is related to $L E T$, and is a surrogate for $R B E$ in radiation protection at low doses. Since $R B E$ is observed to be higher for higher $L E T$, quality factors are defined in terms of $L E T$ (Table 6).

For this work, absorbed dose, rather than any of the equivalent dose or effective dose quantities, is used, and doses are quoted in grays (Gy).

Table 6. Linear energy transfer (LET), relative biological effectiveness (RBE), and quality factor $Q$ or radiation weighting factor $w_{T}$. The $Q$ and $w_{T}$ values are considered to be valid below 0.25 $\mathrm{Sv}$, and the $R B E$ values diminish with increasing dose.

\begin{tabular}{lccc}
\hline Radiation & $\boldsymbol{L E T}$ & $\boldsymbol{R B E}$ & $\boldsymbol{Q}$ or $\boldsymbol{w}_{\boldsymbol{T}}(\mathbf{S v} / \mathbf{G y})$ \\
\hline$\alpha$ & high & $10-100$ & 20 \\
neutron & high & $2-100$ & 20 \\
$\beta, \mathrm{e}^{-}$ & low & $1-4$ & 1 \\
$\gamma, \mathrm{x}$ ray & low & $0.5-1.5$ & 1 \\
\hline
\end{tabular}

\subsubsection{Dose and Its Distribution in Time}

For prompt and delayed sub-lethal effects, the higher the dose is, the sooner the response will occur, the more severe the response will be, and the greater the fraction of irradiated persons experiencing the response will be. The classic review by the NCRP of dose, dose rate, and dose fractionation (delivering a dose in several separate irradiations) is still current (NCRP 1980). The NCRP concluded that, if irradiation takes place for times that are longer than the repair times for the kinds of cells and tissues irradiated, a greater dose is needed to produce a given effect. Since such repair times are in the range of 1 to 24 hours, irradiations that take place over periods of hours or days are likely to have less effect per unit dose than irradiations that take place in seconds or minutes. The survivors of the nuclear bombings in Japan in 1945 received $90 \%$ of their dose within 5 seconds, regardless of the distance from the hypocenter (Glasstone and Dolan 1977) (p. 341). Thus, those irradiations were essentially complete before any repair processes could begin.

On the other hand, many orphan source accidents have involved irradiation periods of hours, days, or even weeks, e.g., the ${ }^{60} \mathrm{Co}$ accident in Mexico in 1962 (Andrews 1963). In such cases, one would expect significant repair of radiation damage during the exposure.

The effect of a given dose is strongly dependent on dose rate and dose fractionation. This can be expressed as a dose- and dose rate-effectiveness factor (DDREF) (NCRP 1980; National Research Council 1990). High dose rates are more effective per unit dose than low dose rates (Table 7). 
Table 7. Summary of Dose-Rate Effectiveness Factors for Low-LET Radiation (BEIR V Table 14., p. 23, 1990)

\begin{tabular}{lccc}
\hline Source of Data & $\begin{array}{c}\text { Observed Full } \\
\text { Range of Values }\end{array}$ & $\begin{array}{c}\text { Limited for Narrow } \\
\text { Range of Values }\end{array}$ & $\begin{array}{c}\text { Single Best } \\
\text { Estimate }\end{array}$ \\
\hline Human leukemia (BEIR V) & - & - & 2.1 \\
BEIR III & - & - & 2.0 to 2.5 \\
Laboratory animal studies & & & \\
Specific locus mutation & $3-10$ & $3-7$ & 5 \\
Reciprocal translocation & $5-10$ & $5-7$ & 5 \\
Life shortening & $3-10$ & $3-5$ & 4 \\
Tumorigenesis & $2-10$ & $2-5$ & 4 \\
\hline
\end{tabular}

\subsubsection{Kind and Degree of Medical Care}

Haskin et al. (1997) evaluated

- minimal medical treatment

- supportive medical treatment with growth factors, and

- supportive medical treatment without growth factors.

Intensive medical treatment, including reverse isolation laminar flow rooms such as found in some hospital burn units, were not evaluated. 


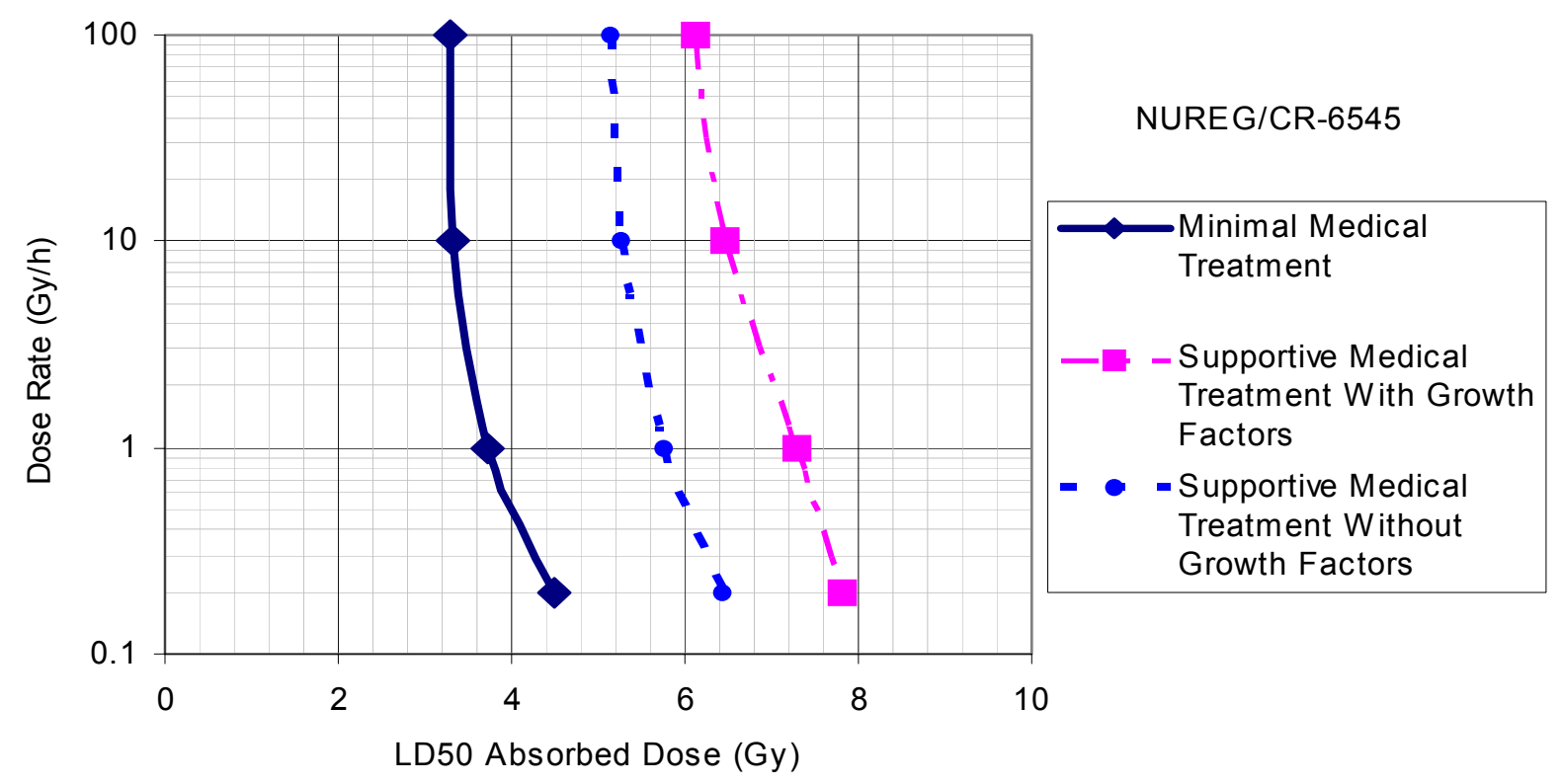

Figure 2. Effect of medical treatment and dose rate on the $L D_{50}$ from gamma radiation (digitized data from Haskin et al. 1997)

Figure 1Figure 1 shows a dramatic difference, almost 2-fold, in the $L D_{50}$ values between minimal medical treatment and supportive medical treatment with growth factors, as determined by the expert elicitation in Haskin et al. 1997. These data are given in Table 8.

Table 8. $L D_{50}$ values (Gy) digitized from graphs in Haskin et al. (1997) as a function of dose rate and degree of medical treatment

\begin{tabular}{cccc}
$\begin{array}{c}\text { Gamma Dose } \\
\text { Rate }(\text { Gy } / \mathrm{h})\end{array}$ & $\begin{array}{c}\text { Minimal } \\
\text { Medical } \\
\text { Treatment }\end{array}$ & $\begin{array}{c}\text { Supportive Medical } \\
\text { Treatment Without } \\
\text { Growth Factors }\end{array}$ & $\begin{array}{c}\text { Supportive Medical } \\
\text { Treatment With } \\
\text { Growth Factors }\end{array}$ \\
\hline 0.2 & 4.50 & 6.42 & 7.81 \\
1 & 3.72 & 5.76 & 7.29 \\
10 & 3.32 & 5.27 & 6.47 \\
100 & 3.29 & 5.15 & 6.13
\end{tabular}

\subsubsection{Uniformity of Irradiation}

People may receive fairly uniform whole-body irradiation, as was the case for many of the Japanese survivors of the nuclear bombings in World War II. However, non-uniform irradiation is seen in many accidents or medical procedures, or following intakes of many radionuclides.

External irradiation can be highly non-uniform if parts of the body are much closer to a small 
source than other parts. If a person unknowingly puts a radioactive source in his pocket, for example, local doses can be many orders of magnitude greater than the average whole body or bone marrow dose. Similarly, collimated beams of radiation may be present either deliberately, as with medical x-ray machines and linear accelerators, or inadvertently, as in many accidental situations.

Inhalation of insoluble alpha- and beta-emitting radioactive materials may lead primarily to irradiation of the lung.

Dermal contact with beta-emitting radioactive materials that remain in contact with the skin for extended periods of time may result predominantly in irradiation of the skin.

Intakes of some radionuclides, e.g., most chemical forms of ${ }^{3} \mathrm{H}$ (tritium), or radioactive alkali metals (e.g., $\mathrm{Na}, \mathrm{K}, \mathrm{Rb}, \mathrm{Cs}$ ) may result in highly uniform irradiation. Intakes of other radionuclides may result in very non-uniform irradiation, as is the case with bone-seeking radionuclides like $\mathrm{Ca}, \mathrm{Sr}, \mathrm{Ba}$ and $\mathrm{Ra}$. Transuranics like $\mathrm{Pu}$ and $\mathrm{Am}$ preferentially irradiate bone and liver. The radioiodines and technetium are concentrated in the thyroid, which then receives much larger doses than other tissues and organs. Soluble uranium leads to relatively large doses to the kidneys.

Clinicians must deal with non-uniform or partial-body irradiation based on symptoms, rather than on average doses. Often dose estimates are not available in time to guide treatment of highdose irradiation victims.

\subsubsection{Age at Exposure}

Age at exposure is an important effect modifier for acute irradiation, but there is a paucity of data on age-dependence for early health effects. One can conclude only that the very young and the elderly will experience most deterministic symptoms at somewhat lower doses than healthy people between ages 20 and 65 .

Developmental abnormalities are significant only for those who are developing, so irradiation of the embryo, fetus, newborns, infants, children, and adolescents can have effects that irradiation of adults cannot, as reviewed in Annex I of UNSCEAR 1993. Results of studies of children who were in utero at the time of irradiation by the nuclear detonations in Japan in 1945 have clearly shown the highest risk of severa mental retardation between weeks 8 and 15 of gestation, somewhat lower risks from weeks 16 through 25 , and lower risks before and after these times (Annex H, UNSCEAR 1993).

Age is a key variable for the late effect of carcinogenesis, with those irradiated as children suffering higher risks than those irradiated as adults. In particular, there was an epidemic of over 1000 excess thyroid cancers in persons who were children when they were exposed to the radioiodine releases from Chernobyl, but little, if any, thyroid cancer in adults (Heidenreich et al. 2000; Jacob et al. 1998). 


\subsubsection{Sex}

Sex doesn't emerge as a key effect modifier for early health effects, but does make a big difference for cancer susceptibility. In particular, the female breast is a highly radiosensitive tissue (ICRP 1991), and the female thyroid is twice as sensitive to radiation carcinogenesis as the male thyroid (NCRP 1985).

\subsubsection{Genetic Susceptibility}

Some individuals have inherited deficient mechanisms of DNA repair, and such persons are more susceptible to ionizing radiation both for early effects and for late effects.

\subsubsection{Adaptive Response}

The phenomenon of adaptive response is well-established for some cellular endpoints (Annex B) (UNSCEAR 1994). Typically, an experimental group is irradiated with a small "priming dose" hours or days before being irradiated with a large "challenge dose." There is clear evidence of up-regulation of DNA repair processes following priming doses on the order of $0.1 \mathrm{~Gy}$ (10 rads), and that this enhanced repair may persist for days or perhaps weeks, depending on the experimental system. However, at this time, there is no firm evidence that a priming dose, say, the day before a large challenge dose, would affect the dose-response relationships for hematopoietic syndrome.

\subsubsection{Other Effect Modifiers: Cell Cycle, Trauma, Chemical Exposure, Nutrition, Infection}

For cell-killing, cell sensitivity to radiation depends on where a cell is in its cell cycle. In a typical organism, cells are randomly distributed throughout the cell cycle (Hall 2000), so this effect is not generally seen in mature organisms.

Chemicals can affect cell sensitivity to radiation killing (Annex H) (UNSCEAR 2001). Oxygen sensitizes, while free radical scavengers protect (Hall 2000).

Trauma or infection will clearly complicate radiation injury, and may lower the dose at which symptoms appear (Anno and Bloom 2002).

Modifiers exist that greatly affect the risk of late effects, specifically, carcinogenesis. Genetic susceptibility, hormonal status, exposure to tumor promoters or protease inhibitors, nutrition and diet, and the state of infection are all know to significantly modulate cancer risk.

At this time, it is not possible to quantitatively describe the effect modification of the other effect modifiers listed here. 


\section{Death as a Result of Deterministic Health Effects of Radiation}

As a health outcome, death may be the result of any of five acute radiation syndromes. These are

- the bone marrow or hematopoietic syndrome

- the gastrointestinal (GI) syndrome

- the cerebrovascular syndrome

- the pulmonary syndrome, and

- the cutaneous syndrome.

Each of these syndromes is preceded by prodromal symptoms (Hall 2000).

Table 9. Acute radiation syndromes (first four from NCRP Report No. 98)

\begin{tabular}{lcl}
\hline Syndrome & Acute dose (Gy) & Characteristics/Sequellae \\
\hline $\begin{array}{l}\text { Subclinical } \\
\text { syndrome }\end{array}$ & $<2$ & Subclinical \\
$\begin{array}{l}\text { Hematopoietic } \\
\text { syndrome }\end{array}$ & $2-4$ & $\begin{array}{l}\text { Granulocytopenia, thrombocytopenia, hemorrhage, } \\
\text { infection, electrolyte imbalance }\end{array}$ \\
$\begin{array}{l}\text { Gastrointestinal } \\
\text { syndrome }\end{array}$ & $6-10$ & $\begin{array}{l}\text { Lethargy, diarrhea, dehydration, degeneration of } \\
\text { bowel epithelium, death in 10-14 days }\end{array}$ \\
$\begin{array}{l}\text { Central Nervous } \\
\text { syndrome }\end{array}$ & $>10$ & $\begin{array}{l}\text { Agitation, apathy, disorientation, disturbed } \\
\text { equilibrium, vomiting, opisthotonus, convulsions, } \\
\text { prostration, coma, death in 1-2 days }\end{array}$ \\
$\begin{array}{l}\text { Pulmonary } \\
\text { syndrome }\end{array}$ & $9-40$ (beta) & Radiation pneumonitis \\
$\begin{array}{l}\text { Cutaneous } \\
\text { syndrome }\end{array}$ & 40 (beta) & Severe ulceration of skin, necrosis, sepsis \\
\hline
\end{tabular}

Additionally, death may occur from high-dose partial body irradiation that results in necrosis or desquamation that leads to infection.

In 1906, a decade after the discovery of radiation, Bergonie and Tribondeau stated that radiation is "...more effective on cells which have a greater reproductive activity; the effectiveness is greater on those cells which have a longer dividing future ahead, on those cells the morphology and function of which is least fixed." In other words, cells and tissues that are undifferentiated or rapidly growing or both are the most radiosensitive.

Radiation therapy for cancer works on this principle, since cancer cells are more rapidly dividing than non-cancerous tissue, they can be killed by radiation while sparing the more slowlygrowing non-cancerous tissue. The hematopoietic and gastrointestinal radiation syndromes can 
be understood on this principle. "Death is caused by the depletion of the stem cells of a critical self-renewal tissue: the epithelium of the gut or the circulating blood cells, respectively" (Hall 2000). The cutaneous syndrome can also be understood this way. However, according to Hall (2000), "[t]he exact cause of death in the cerebrovascular syndrome is by no means clear."

\subsection{Dose-Response Relationships (DRRs) for Hematopoietic Syndrome Mortality}

The lowest-dose radiation syndrome that can result in death is the hematopoietic syndrome. It results in what is commonly termed "bone marrow death." The hematopoietic syndrome is characterized by granulocytopenia, thrombocytopenia, hemorrhage, infection, and electrolyte imbalance.

After acute irradiation, death, if it occurs from hematopoietic syndrom, will take place within 60 days. If irradiation occurs at lower dose rates, survival may be longer.

Beginning in 1997, a joint European Commission/U.S. Nuclear Regulatory Commission published reports on uncertainty in health effects modeling for both early (Goossens and Harper 1998; Haskin et al. 1997b) and late (Little et al. 1997b) radiation effects. The results of these studies are based on the equally-weighted averages of estimates elicited from an international panel of experts.

Figure 2 shows graphs displaying the threshold for mortality, the $L D_{10}$, the $L D_{50}$, and the $L D_{90}$, with each central value shown with $5 \%$ and $95 \%$ confidence limits (horizontal bars), as a function of dose rate from $0.2 \mathrm{~Gy} / \mathrm{h}$ to $100 \mathrm{~Gy} / \mathrm{h}$. The data in this series of figures were digitized from the graphs in Haskin et al. 1997, since tables of the "Equal Weight" values were not included in the report or its Appendix. Note that, as the dose rate drops, $L D_{50}$ values increase, as does uncertainty. 

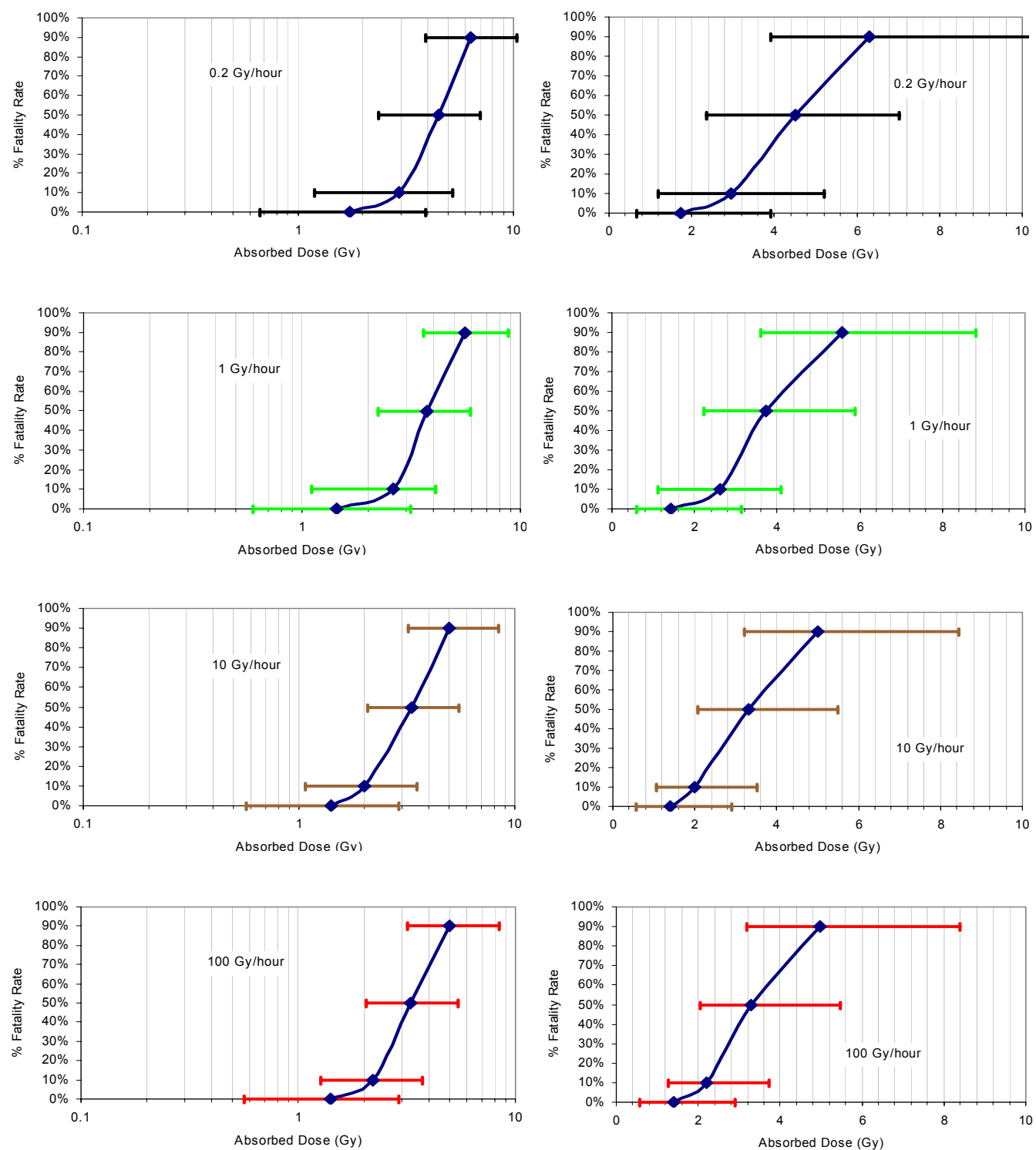

Figure 3. Plots from the NRC/EUR uncertainty analysis of fatality rate (no medical care) from hematopoietic syndrome for $0.2,1,10$, and $100 \mathrm{~Gy} / \mathrm{y}$ dose rates. Left hand graphs are plotted on a logarithmic dose scale; right hand graphs on a linear dose scale. Each point has "equal weighting" estimates of the lower $5 \%$ ile and upper $95 \%$ ile confidence limits from the panel of experts. Data digitized from graphs in (Haskin et al. 1997b).

The most recent review of $L D_{50}$ values based only on human data was done by Anno (Anno et al. 2003), but these do not include uncertainty. These results are shown in Table 10 and Figure 3. 


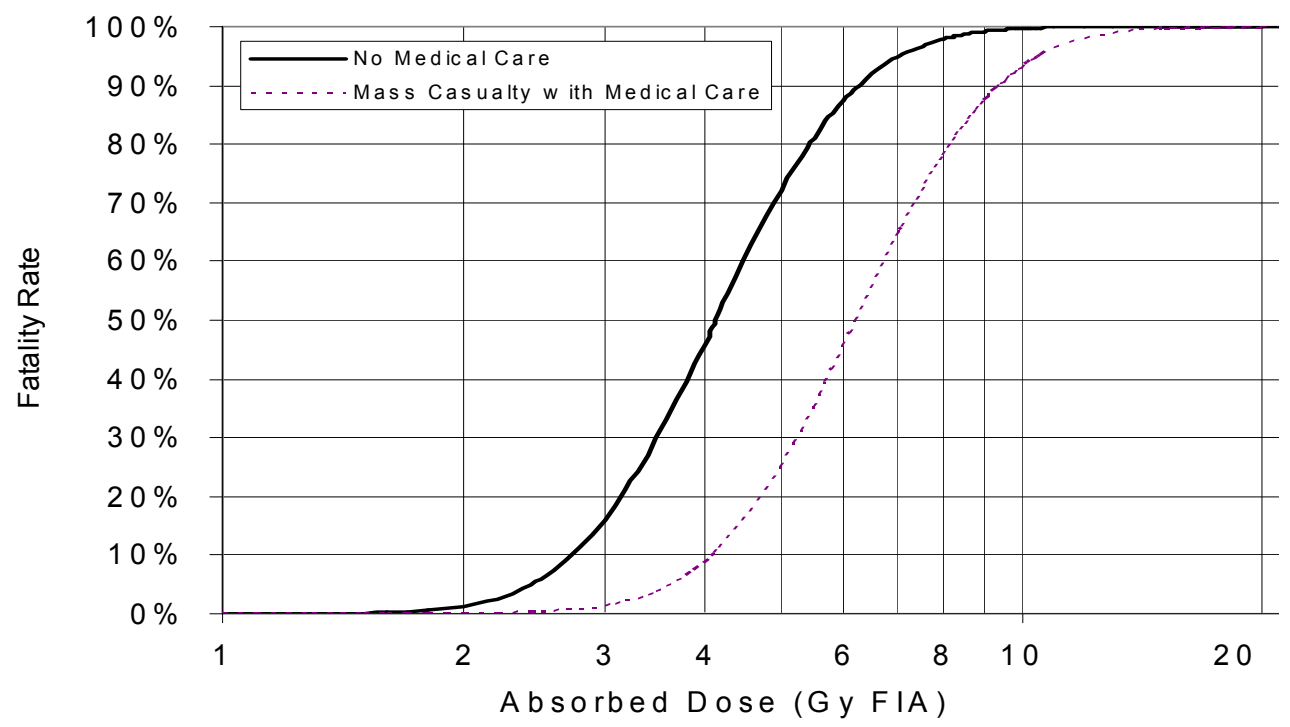

Figure 4. Fatality rate from hematopoeitic syndrome following acute radiation exposure (adapted from Anno et al. 2003). $L D_{50}$ is 4.14 Gy for no medical care, and $1.5 \times$ higher $(6.21 \mathrm{~Gy})$ for mass casualties with medical care. These are lognormal distributions with GSDs of 1.381 .

Table 10. Results of Anno et al. (2003) and NUREG/CR-6545 (Haskin et al. 1997) presented as percentiles of distribution. Table entries are acute doses at which \%ile of deaths will occur.

\begin{tabular}{|c|c|c|c|c|c|c|}
\hline$\%$ ile & $\begin{array}{l}\text { Anno et al. } \\
\text { (2003) No } \\
\text { Medical Care } \\
\text { Dose (Gy) }\end{array}$ & $\begin{array}{l}\text { Anno et al. } \\
\text { (2003) Mass } \\
\text { Casualty } \\
\text { Medical Care } \\
\text { Dose (Gy) }\end{array}$ & $\begin{array}{l}\text { NUREG/ } \\
\text { CR-6545 } \\
0.2 \mathrm{~Gy} / \mathrm{h} \\
\end{array}$ & $\begin{array}{c}\text { NUREG/ } \\
\text { CR-6545 } \\
1 \mathrm{~Gy} / \mathrm{h} \\
\end{array}$ & $\begin{array}{c}\text { NUREG/ } \\
\text { CR-6545 } \\
10 \mathrm{~Gy} / \mathrm{h} \\
\end{array}$ & $\begin{array}{l}\text { NUREG/ } \\
\text { CR-6545 } \\
100 \mathrm{~Gy} / \mathrm{h} \\
\end{array}$ \\
\hline 0.01 (or threshold) & 1.25 & 1.87 & 1.74 & 1.44 & 1.41 & 1.41 \\
\hline 0.1 & 1.53 & 2.29 & & & & \\
\hline 1 & 1.95 & 2.93 & & & & \\
\hline 5 & 2.43 & 3.65 & & & & \\
\hline 10 & 2.74 & 4.11 & 2.94 & 2.62 & 2.00 & 2.20 \\
\hline 50 & 4.14 & 6.21 & 4.50 & 3.72 & 3.32 & 3.29 \\
\hline 90 & 6.26 & 9.39 & 6.31 & 5.57 & 4.99 & 4.96 \\
\hline 95 & 7.04 & 10.6 & & & & \\
\hline 99 & 8.77 & 13.2 & & & & \\
\hline 99.9 & 11.2 & 16.8 & & & & \\
\hline 99.99 & 13.8 & 20.6 & & & & \\
\hline
\end{tabular}

There is fairly good agreement, and the Anno et al. results are well within the uncertainty ranges 
of the Haskin et al. results. Figure 4 compares Anno et al. (2003) predictions with the dose-rate dependent central point predictions of the NRC/EUR expert group. The results of Anno et al. are seen to be bracketed by the earlier work.

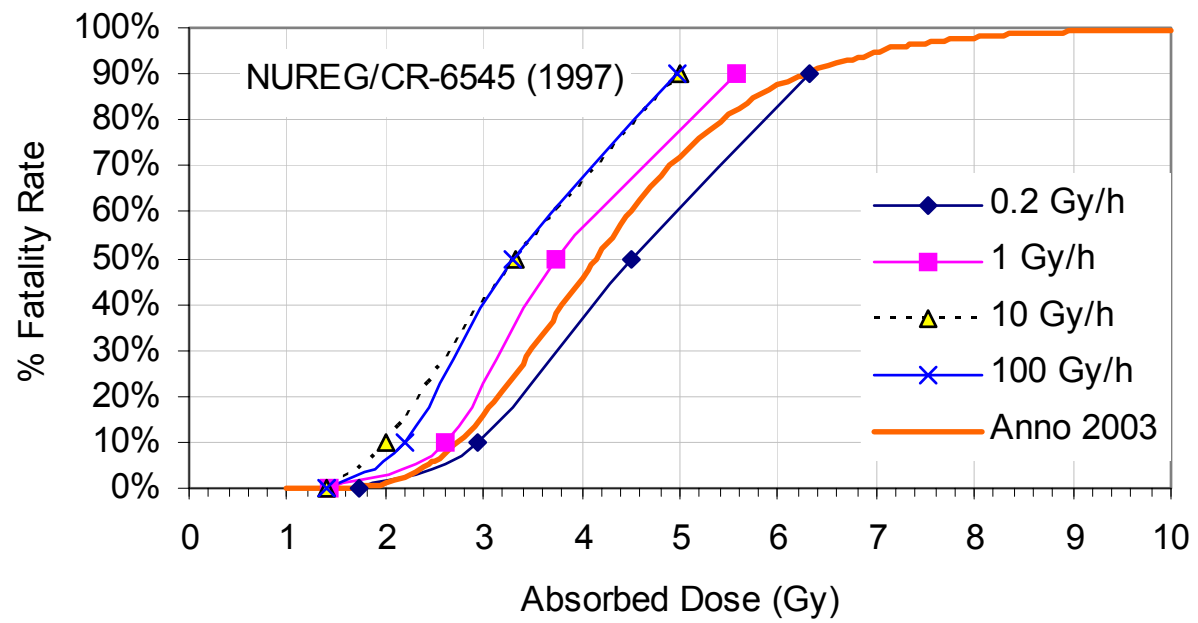

Figure 5. Central results from the NRC/EUR uncertainty analysis for 4 dose rates plotted along with analysis by Anno et al. (2003). All cases represent no medical care.

\subsection{Gastorintestinal Syndrome}

The gastrointestinal (GI) syndrome is characterized by lethargy, diarrhea, dehydration, degeneration of bowel epithelium, and death in 10-14 days (NCRP 1989).

Following acute irradiation, death from the gastrointestinal (GI) syndrome will take place within days to a few weeks. Hall states that the GI syndrome does not cause death "until 5 to 10 days after irradiation." There is no human experience with the GI syndrome at lower dose rates.

$L D_{50}$ values for the GI syndrome from Haskin et al. 1997 are shown in Figure 5 and Table 11. Even if people survive the GI syndrome, they still face the hematopoietic syndrome. 


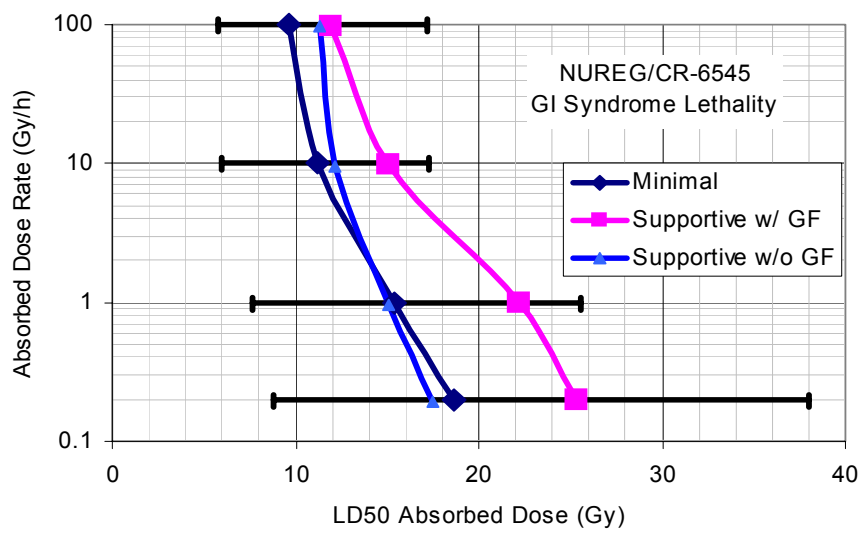

Figure 6. $L D_{50}$ values for gastrointestinal (GI) syndrome lethality at 4 dose rates and 3 levels of medical treatment: minimal, supportive with growth factor, and supportive without growth factor. 5\% and 95\% confidence limits are shown for the minimal medical treatment only. Plotted from digitized data displayed in Haskin et al. 1997.

Table 11. $L D_{50}$ for GI syndrome as a function of dose rate and medical treatment

\begin{tabular}{lcccc}
\hline Source in Haskin et al. 1997 & $\begin{array}{c}\text { Dose } \\
\text { rate } \\
(\mathrm{Gy} / \mathrm{h})\end{array}$ & $\begin{array}{c}5 \% \text { lower } \\
\text { confidence } \\
\text { interval }\end{array}$ & $\begin{array}{c}\text { Midpoint of } \\
\text { confidence } \\
\text { interval }\end{array}$ & $\begin{array}{c}95 \% \text { upper } \\
\text { confidence } \\
\text { interval }\end{array}$ \\
\hline $\begin{array}{l}\text { Figure 4.6. } L D_{50} \text { for } \\
\text { gastrointestinal syndrome, }\end{array}$ & 100 & 5.78 & 9.65 & 17.22 \\
minimal medical treatment & 10 & 5.92 & 11.22 & 17.25 \\
& 1 & 7.64 & 15.39 & 25.5 \\
Figure 4.7a. $L D_{50}$ for & 0.2 & 8.79 & 18.67 & 38.04 \\
gastrointestinal syndrome, & 100 & 8.71 & 11.95 & 16.73 \\
supportive medical treatment, & 10 & 9.23 & 15.09 & 21.75 \\
with growth factors & 1 & 14.77 & 22.16 & 29.52 \\
& 0.2 & 17.23 & 25.36 & 33.57 \\
Figure 4.7b. $L D_{50}$ for & 100 & 7.7 & 11.35 & 19.3 \\
gastrointestinal syndrome, & 10 & 8.16 & 12.1 & 19.26 \\
supportive medical treatment, & 1 & 8.17 & 15.04 & 26.55 \\
without growth factors & 0.2 & 12.43 & 17.51 & 33.27
\end{tabular}




\subsection{Pulmonary Syndrome}

The pulmonary syndrome was presented in (Evans et al. 1993) and was analyzed by the joint EC/USNRC expert group (Haskin et al. 1997a; Haskin et al. 1997b). The pulmonary syndrome is further divided into exposures from alpha and beta emitters.

Following acute irradiation, death from the pulmonary syndrome will take place within days (extremely high doses) to months.

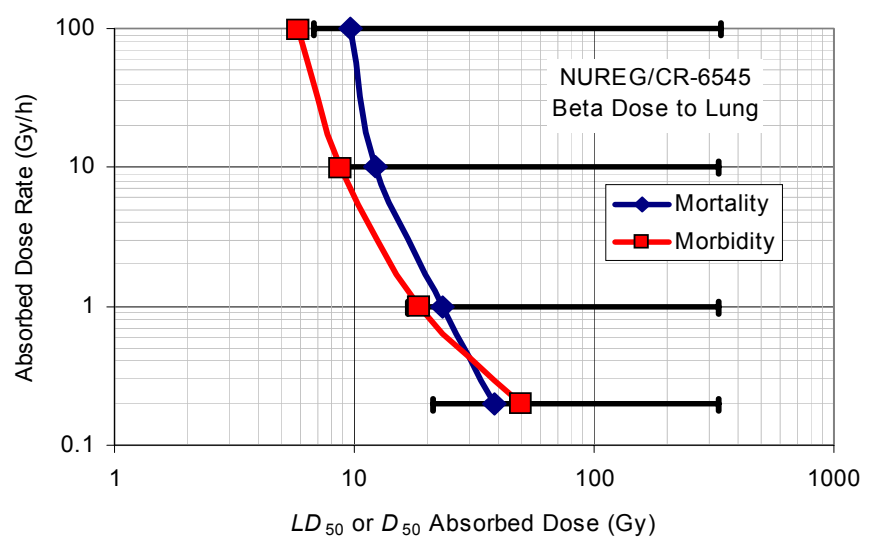

Figure 7. $L D_{50}$ for mortality from beta lung exposure and $D_{50}$ for morbidity from beta lung exposure. Digitized data from graphs in Haskin et al. 1997. 95\% confidence values are highly skewed due to estimates of one of seven experts. 
Table 12. $L D_{50}$ for mortality from beta lung exposure and $D_{50}$ for morbidity from beta lung exposure. Digitized data from graphs in Haskin et al. 1997

\begin{tabular}{lcccc}
\hline & $\begin{array}{c}\text { Dose } \\
\text { rate } \\
(\mathrm{Gy} / \mathrm{h})\end{array}$ & $\begin{array}{c}\text { 5\% lower } \\
\text { confidence } \\
\text { interval }\end{array}$ & $\begin{array}{c}\text { Midpoint of } \\
\text { confidence } \\
\text { interval }\end{array}$ & $\begin{array}{c}\text { 95\% upper } \\
\text { confidence } \\
\text { interval }\end{array}$ \\
\hline Figurce in Haskin et al. (1997) & 100 & 6.76 & 9.63 & 338 \\
exposure $L D_{50}$ for beta lung & 10 & 8.24 & 12.2 & 333 \\
& 1 & 16.6 & 23.4 & 330 \\
& 0.2 & 21.4 & 38.1 & 332 \\
Figure 4.9. $D_{50}$ for morbidity due to & 100 & 3.35 & 5.86 & 74 \\
beta lung exposure & 10 & 4.21 & 8.74 & 72.9 \\
& 1 & 9.2 & 18.7 & 73 \\
& 0.2 & 14.7 & 49.7 & 130 \\
\hline
\end{tabular}

The 95\% confidence values displayed in Figure 6 and Table 12 are strongly skewed upward due to very high estimates by one of the seven experts. The experts' numbers are plotted in Figure 7, taken directly from Haskin et al. 1997.

In Annex $\mathrm{G}$ of (UNSCEAR 1993), the $E D_{50}$ for radiation pneumonitis is about $9.5 \mathrm{~Gy}$ in medical irradiation cases. 


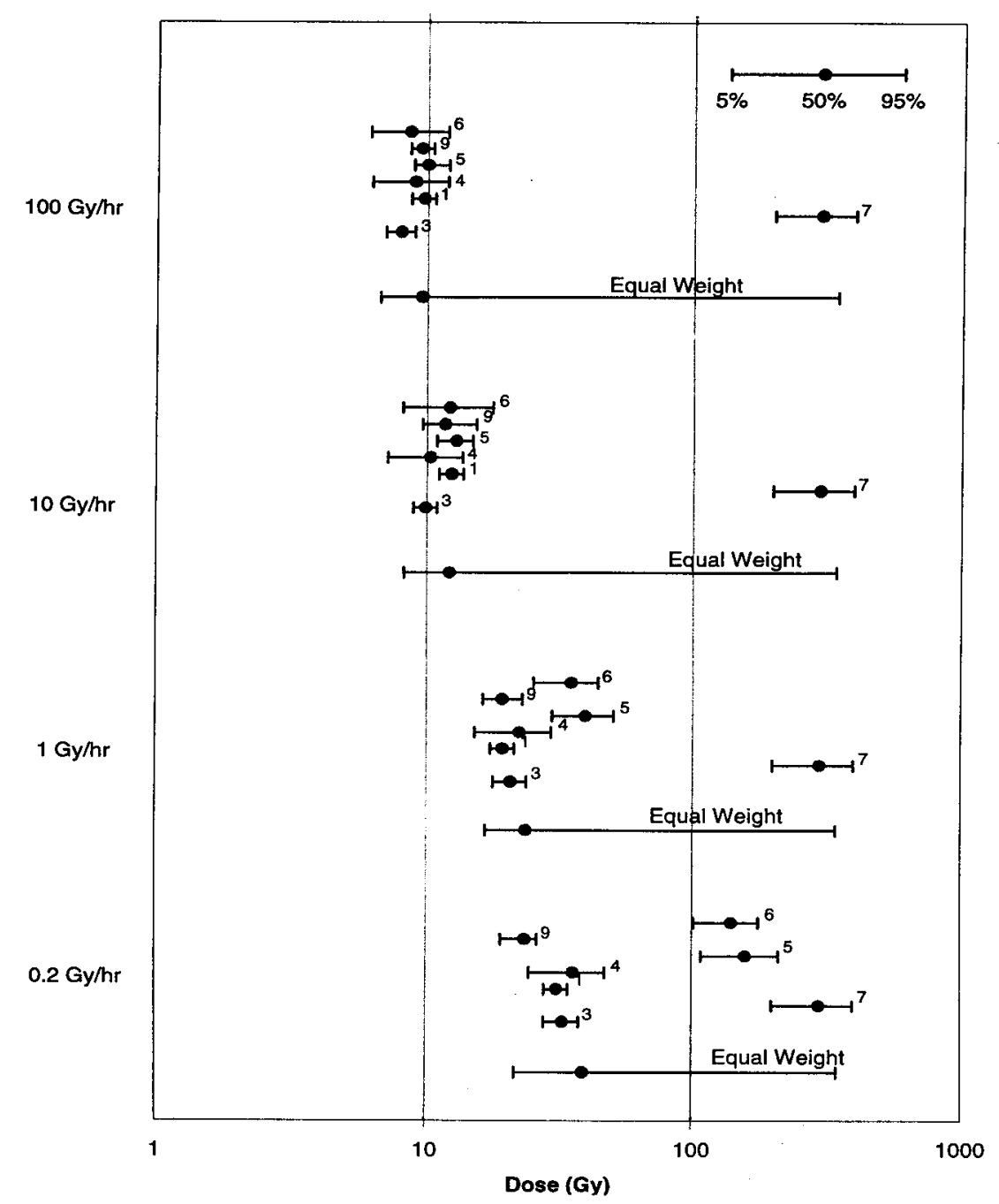

Figure 8. Experts' judgments on $L D_{50}$ for mortality due to beta lung exposure (Figure 4.9 from Haskin et al. 1997). The $95 \%$ values are skewed upward by Expert 7.

The "equal weight" average of three experts" estimates of the alpha particle absorbed dose rate to lung that would cause $50 \%$ mortality was $0.0011 \mathrm{~Gy} / \mathrm{h}$, with a $5 \%$ confidence value of $0.000228 \mathrm{~Gy} / \mathrm{y}$ and a $95 \%$ conficence value of $0.00414 \mathrm{~Gy} / \mathrm{h}$ (Haskin et al. 1997b).

\subsection{Cutaneous Syndrome}

The cutaneous syndrome, has recently been named, and it may exist along with the others if skin doses are very high (Gottlober et al. 2001; Peter 2002; Peter 2002; Peter, Steinert, and Gottlöber 2002). Such high skin doses in the absence of lethal whole-body irradiation are possible from weakly-penetrating beta-emitting radioactive material on the skin, and are known as "beta 
burns." There is some disagreement on whether the cutaneous syndrome constitutes a separate syndrome, but there is no doubt high-dose, deterministic radiogenic skin injury complicated the treatment of many of the high-dose casualties at Chernobyl and some have suggested that, absent the cutaneous injury, fewer Chernobyl first-responders would have died.

Death from the cutaneous syndrome could result in days or longer, depending on other conditions, such as dose rate and medical care.

Table 13. Selected Skin and Tissue Effects of Acute Exposure (<1 day) (USNRC 1989)

\begin{tabular}{ccccc}
\hline \multirow{2}{*}{$\begin{array}{c}\text { ED\% denotes } \\
\text { effective threshold } \\
\text { (per cent prevalence) }\end{array}$} & \multicolumn{2}{c}{ Early effects } & \multicolumn{2}{c}{ Late effects } \\
\cline { 2 - 5 } & Erythema & Desquamation & Necrosis & Lens opacities \\
\hline ED10 & 4.0 & 14.0 & 20.0 & 2.0 \\
ED50 & 5.75 & 20.0 & 25.0 & 5.0 \\
ED90 & 7.5 & 26.0 & 35.0 & 10.0 \\
\hline
\end{tabular}

The top half of Table 14 shows doses and confidence intervals for acute ulceration from 24-hour beta skin irradiation as a function of percent of skin exposed. There is no effect of percent of skin exposed. The bottom half of Table 14 shows doses required to produce $10 \%, 50 \%$, and $90 \%$ acute ulceration when $40 \%$ of skin is irradiated, with lower and upper confidence intervals (digitized from Haskin et al. 1997). 
Table 14. Acute ulceration from beta exposure of skin (digitized from Haskin et al. 1997). Entries are absorbed dose in grays

$\begin{array}{lcccc}\text { Source in Haskin et al. (1997) } & \begin{array}{c}\text { \% Skin } \\ \text { Exposed }\end{array} & \begin{array}{c}\text { 5\% lower } \\ \text { confidence } \\ \text { interval }\end{array} & \begin{array}{c}\text { Midpoint of } \\ \text { confidence } \\ \text { interval }\end{array} & \begin{array}{c}95 \% \text { upper } \\ \text { confidence } \\ \text { interval }\end{array} \\ \begin{array}{l}\text { Figure 4.11. Threshold for acute } \\ \text { ulceration from 24-hour beta skin }\end{array} & 60 \% & 15.5 & 40.7 & 163 \\ \text { dose } & 40 \% & 16.4 & 40.5 & 161 \\ & 20 \% & 17.3 & 40.2 & 160 \\ & \begin{array}{c}\text { \% Acute } \\ \text { Ulceration }\end{array} & \begin{array}{c}5 \% \text { lower } \\ \text { confidence } \\ \text { interval }\end{array} & \begin{array}{c}\text { Midpoint of } \\ \text { confidence } \\ \text { interval }\end{array} & \begin{array}{c}95 \% \text { upper } \\ \text { confidence } \\ \text { interval }\end{array} \\ \begin{array}{l}\text { Figure 4.12. 24-hour beta skin dose } \\ \text { for acute ulceration in specified }\end{array} & 90 \% & 20.5 & 40.5 & 913 \\ \begin{array}{l}\text { fraction of exposed skin (40\% of } \\ \text { total skin exposed), supportive }\end{array} & 50 \% & 19.4 & 35.3 & 575 \\ \text { medical treatment } & 10 \% & 18.4 & 30.3 & 261\end{array}$

There was no consensus among the two experts willing to estimate fraction of persons who would die from $50 \%$ acute ulceration of exposed skin following a 24-hour beta skin dose for $40 \%$ or $60 \%$ of skin exposed, but the three who responded at $20 \%$ of skin exposed agreed that mortality would probably be zero and would not exceed 10\% (Haskin et al. 1997, Figure 4.13). Nor was there consensus among those two experts concerning mortality following $90 \%$ acute ulceration of $20 \%, 40 \%$, or $60 \%$ of exposed skin. Central estimates were that mortality would be $16 \%, 36 \%$, and $75 \%$, respectively, for persons with $90 \%$ acute ulceration on the $20 \%, 40 \%$, or $60 \%$ of their skin that was exposed (Haskin et al. 1997, Figure 4.14).

\subsection{Cerebrovascular Syndrome}

Death from the cerebrovascular (CV) syndrome can occur essentially instantly at very high doses, and from minutes to tens of hours at lower dose rates. Hall (2000) describes two cases that died at 35 and 49 hours after acute irradiation. Unconsciousness may occur within minutes of doses on the order of $100 \mathrm{~Gy}$.

The CV syndrome is characterized by agitation, apathy, disorientation, disturbed equilibrium, vomiting, opisthotonus, convulsions, prostration, coma, and death in 1-2 days (NCRP 1989).

While life may be prolonged for some time with heroic medical intervention, as in the case of two of the victims of the Tokai-Mura, Japan, criticality accident on September 30, 1999, there is very little chance of surviving an acute whole-body dose of 10 to 20 Gy of mixed neutrons and photons. One victim survived 82 days, the other 210 days, but neither had any quality of life 
after the accident.

4.6 Other Deterministic Health Effects

There are many other deterministic health effects listed in Table 2 that bear brief discussion.

\subsubsection{Teratogenesis}

Teratogenic (from Greek "terato," monster) effects are effects on unborn children, usually developmental effects. These are all threshold effects.

Teratogenic effects seen in human populations include microcephaly (small skull and brain); mental retardation: a somatic effect whose frequency and severity are dose-dependent; deformities; growth retardation; and miscarriages

4.6.2 Late Noncancer Effects: Heart Disease, Stroke, Digestive Diseases, and Respiratory Diseases

"The evidence for radiation effects on noncancer mortality remains strong, with risks elevated by about $14 \%$ per sievert during the last 30 years of follow-up. Statistically significant increases are seen for heart disease, stroke, digestive diseases, and respiratory diseases. The noncancer data are consistent with some non-linearity in the dose response owing to the substantial uncertainties in the data. There is no direct evidence of radiation effects for doses less than about $0.5 \mathrm{~Sv}$ " (Preston et al. 2003).

\subsubsection{Impaired Fertility and Temporary or Permanent Sterility}

Fertility is affected differently by ionizing radiation in females (Table 15) and males (Table 16). 
Table 15. Effects of Acute Exposure on Ovarian Function (USNRC 1989)

Ovarian dose (Gy) Effect

$0.6 \quad$ No effect

1.5 Some risk for ovulatory suppression in women $>40$ years of age

2.5-5.0 In women aged 15-40, 60\% may suffer permanent ovulatory suppression; remainder may suffer temporary amenorrhea. In women $>40$ years of age, 100\% may have permanent ovulation suppression. Menopause may be artificially produced

5-8 In women aged $15-40,60-70 \%$ may suffer permanent ovulatory suppression; remainder may experience temporary amenorrhea. No data for women $>40$ years of age

$>8 \quad 100 \%$ ovulation suppression

Table 16. Effects of Fractionated Testicular Irradiation on Sperm Count (USNRC 1989)

\begin{tabular}{cl}
\hline Testicular dose (Gy) & Effect \\
\hline $0.1-0.3$ & Temporary oligospermia \\
$0.3-0.5$ & $\begin{array}{l}100 \% \text { temporary aspermia from 4-12 months post-exposure. Full } \\
\text { recovery by 48 months }\end{array}$ \\
$0.5-1$ & $\begin{array}{l}100 \% \text { temporary aspermia from 3-17 months post-exposure. Full } \\
\text { recovery beginning 8-38 months } \\
1-2\end{array}$ \\
$\begin{array}{l}100 \% \text { temporary aspermia from 2-15 months post-exposure. Full } \\
\text { recovery beginning 11-20 months } \\
100 \% \text { aspermia beginning at 1-2 months post-exposure. No recovery } \\
\text { observed up to 40 months }\end{array}$ \\
\hline
\end{tabular}




\subsubsection{Loss of Pregnancy}

Among survivors at Hiroshima and Nagasaki "were possibly as many as 10,000 pregnant women whose greatest risk was the loss of their pregnancy... [T] his risk appears to have been markedly elevated among those women in the first eight weks of pregnancy, but it was also greater than normal among women in the 8-15 week interval" (Annex H, UNSCEAR 1993).

\subsubsection{Cataract}

Cataracts, or lens opacities, are estimated to occur in $10 \%$ of people receiving $2 \mathrm{~Gy}, 50 \%$ of people receiving $5 \mathrm{~Gy}$, and $90 \%$ of people receiving $10 \mathrm{~Gy}$ (USNRC 1989). Cataracts are also seen in excess in former astronauts, who received doses well under 2 Gy but from very high-LET radiation (Cucinotta et al. 2001). 


\section{Stochastic Effects}

Carcinogenesis and heritable ill-health are the main stochastic effects of concern.

\subsection{Carcinogenesis}

Ionizing radiation is a known, albeit weak, human carcinogen. Based on studies of radium workers including dial painters, underground miners (in particular, uranium miners), survivors of the 1945 nuclear bombings in Japan, medical populations, and other worker populations, doseresponse curves have been formulated.

Cancer is primarily a disease of old age, even when caused by radiation. Radiation carcinogenesis is characterized by a latent period, an interval of time between irradiation and the onset of clinical symptoms. Latent periods are shorter for higher doses. The Life Span Study (LSS) cohort of Japanese nuclear bomb survivors has shown latent periods of 2 to 10 years for leukemia, and 10 or more years for solid tumors.

Radiation carcinogenesis is the subject of many detailed scientific reviews (ICRP 1991; NCRP 2001a; National Research Council 1990; UNSCEAR 2001). In October, 2003, the $13^{\text {th }}$ report following up the LSS cohort for solid tumors and non-cancer endpoints through 1997 was published (Preston et al. 2003).

It is important to realize that there is a significant amount of cancer in human populations in the absence of radiation exposures above background, as shown in Table 17. Even a real increase in cancer incidence following irradiation may be difficult to detect in the presence of so much nonradiogenic cancer. Nonetheless, some of the cancer deaths in Table 17 are believed to be due to radiation exposures to natural, technologically enhanced, and human-made radiation sources. Cancer incidence data from 1973-1999 were made available in November of 2001 (Ries et al. 2002) http://seer.cancer.gov/csr/1973 1999/.

Table 17. US cancer statistics for 1999. Almost 1/4 of US citizens die of cancer.

$552,200 \quad$ US cancer deaths (1999)

$2,339,000 \quad$ US deaths $(4 / 98-3 / 99)$

274,625,507 population of USA (20:09 EDT Apr 17, 2000)

$0.00852 \mathrm{y}^{-1}$ death rate; one in 117 people die each year

$0.00201 \mathrm{y}^{-1} \quad$ cancer death rate; one in 497 people die of cancer each year

$23.6 \%$ of all deaths in USA are due to cancer

In the LSS cohort of " 86,572 people with individual dose estimates", "[t]here have been 9335 
deaths from solid cancer and 31,881 deaths from noncancer diseases during the 47-year followup" (Preston et al. 2003). The authors estimate that " 440 (5\%) of the solid cancer deaths and $250(0.8 \%)$ of the noncancer deaths were associated with the radiation exposure. The excess solid cancer risks appear to be linear in dose even for doses in the 0 to $150-\mathrm{mSv}$ range."

It is believed that there is an increased risk of childhood malignancies due to in utero irradiation, but that the risk is probably no greater than predicted by the BEIR V Committee (National Research Council 1990).

The mechanisms of radiation-induced cancer are very complex. It is believed that radiationinduced mutation of nuclear DNA leads to transformation, often with genomic instability at later stages. Cancer is usually a multi-stage process, with initiation, promotion, and tumor progression (increasing malignancy with time) being common stages. Radiation is a complete carcinogen, because it can both initiate and promote.

Radiogenic cancer risk depends on many variables besides just dose:

- particular kind of cancer

- age at exposure

- attained age

- time since exposure: a latent period between exposure and clinical manifestation

- $\operatorname{sex}$

- magnitude of dose to a particular organ

- radiation $L E T$

- nature of exposure: brief, fractionated, or chronic

- exposure to other carcinogens and promoters (like smoking)

- genetic susceptibility

- lifestyle factors, including diet (presence of carcinogens or absence of protective factors)

- infection

As a result, dose-response functions are simplistic and uncertain.

Cancer dose-response relationships are relative risk (or multiplicative risk) models, that is, an exposure to radiation increases the risk of cancer relative to the underlying cancer background risk.

Cancer types that have been seen in human beings in statistically significant numbers include

- leukemia, especially myeloid; never chronic lymphocytic

- solid tumors: bone surfaces, thyroid, liver, lung, breast, stomach, colon, esophagus, skin

Table 4-2 from the BEIR-V report, gives numerical estimates of cancer risks (Table 18). 
Table 18. Excess Cancer Mortality Estimates and Their Statistical Uncertainty - Lifetime Risks per 100,000 Exposed Persons

\begin{tabular}{|c|c|c|c|c|c|c|}
\hline \multirow[b]{2}{*}{ Exposure Scenario $^{\mathrm{a}}$} & \multicolumn{3}{|l|}{ Male } & \multicolumn{3}{|l|}{ Female } \\
\hline & Total & Nonleukemia $^{\mathrm{b}}$ & Leukemia $^{c}$ & Total & Nonleukemia & Leukemia \\
\hline Single exposure to $0.1 \mathrm{~Sv}(10 \mathrm{rem})$ & 770 & 660 & 110 & 810 & 730 & 80 \\
\hline $90 \%$ confidence limits $^{\mathrm{c}}$ & $540-1,240$ & $420-1,040$ & $50-280$ & $630-1,160$ & $550-1,020$ & $30-190$ \\
\hline Normal expectation & 20,510 & 19,750 & 760 & 16,150 & 15,540 & 610 \\
\hline$\%$ of normal & 3.7 & 3.3 & 15 & 5 & 4.7 & 14 \\
\hline Total years of life lost & 12,000 & & & 14,500 & & \\
\hline $\begin{array}{l}\text { Average years of life lost per excess } \\
\text { death }\end{array}$ & 16 & & & 18 & & \\
\hline $\begin{array}{l}\text { Continuous lifetime exposure to } 1 \\
\mathrm{mSv} / \mathrm{y}(0.1 \mathrm{rem} / \mathrm{y})^{\mathrm{e}}\end{array}$ & 520 & 450 & 70 & 600 & 540 & 60 \\
\hline $90 \%$ confidence limits $^{\mathrm{d}}$ & $410-980$ & $320-830$ & $20-260$ & $500-930$ & $430-800$ & $20-200$ \\
\hline Normal expectation & 20,560 & 19,760 & 790 & 17,520 & 16,850 & 660 \\
\hline$\%$ of normal & 2.5 & 2.3 & 8.9 & 3.4 & 3.2 & 8.6 \\
\hline Total years of life lost & 8,100 & & & 10,500 & & \\
\hline $\begin{array}{l}\text { Average years of life lost per excess } \\
\text { death }\end{array}$ & 16 & & & 18 & & \\
\hline $\begin{array}{l}\text { Continuous exposure to } 0.01 \mathrm{~Sv} / \mathrm{y}(1 \\
\text { rem/y) from age } 18 \text { until age } 65\end{array}$ & 2,880 & 2,480 & 400 & 3070 & 2,760 & 310 \\
\hline $90 \%$ confidence limits $^{\mathrm{e}}$ & $2,150-5,460$ & $1,670-4,560$ & $130-1,160$ & $2,510-4,580$ & $2,120-4,190$ & $110-910$ \\
\hline Normal expectation & 20,910 & 20,140 & 780 & 17,710 & 17,050 & 650 \\
\hline$\%$ of normal & 14 & 12 & 52 & 17 & 16 & 48 \\
\hline Total years of life lost & 42,200 & & & 51,600 & & \\
\hline $\begin{array}{l}\text { Average years of life lost per excess } \\
\text { death }\end{array}$ & 15 & & & 17 & & \\
\hline $\begin{array}{l}{ }^{\text {a }} \text { Based on an equal dose to all organs a } \\
\text { bSum of respiratory, breast, digestive, } \\
{ }^{\mathrm{c}} \text { Estimates for leukemia contain an im } \\
\text { d Additional sources of uncertainty are } \\
\text { A A dose rate reduction factor has not be }\end{array}$ & $\begin{array}{l}\text { ad the commit } \\
\text { nd other cance } \\
\text { licit dose rate } \\
\text { iscussed in } \mathrm{BI} \\
\text { en applied to } \mathrm{t}\end{array}$ & $\begin{array}{l}\text { 's preferred risk } \\
\text { duction factor. } \\
\mathrm{V} \text {, Annex } 4 \mathrm{~F} \text {. } \\
\text { risk estimates } \mathrm{f}\end{array}$ & solid cancer & & earest 10 . & \\
\hline
\end{tabular}

Other, more recent reports, come to nearly the same conclusions for low doses and low dose rates (Eckerman et al. 1999; ICRP 1991; NCRP 2001a; Puskin and Nelson 1994; Puskin, Nelson, and Pawel 1999; UNSCEAR 2001).

Populations irradiated to high doses at high dose rates have increased risk of cancer incidence and mortality, taken as about $10-20 \%$ incidence and perhaps $5-10 \%$ mortality per sievert of effective dose of any radiation or per gray of whole-body absorbed dose low-LET radiation. These figures are arrived at by removing the $D D R E F$ from the low dose estimates. Cancer risks for non-uniform irradiation will be less.

\subsection{Chromosome Aberrations}

Chromosome aberrations in circulating blood cells are seen at doses as low as 0.1 Gy of low-LET radiation. In some cases, this phenomenon is useful in cytogenetic dosimetry as a retrospective 
form of biological dosimetry.

\subsection{Heritable Ill-health}

Heritable ill-health (formerly known as genetic effects) are effects seen in the offspring and descendants of exposed individual(s). These are random (stochastic) effects whose probability of occurrence, not severity, depends on magnitude of dose. There is probably no threshold dose.

Some recovery from passing on heritable ill-health has been seen in female mice, but not in male mice (Russell and Kelly 1982).

Heritable effects are not unique to radiation; 1 in 50 live births has serious genetic problems in absence of radiation exposure. They have been observed in animals. They are not confirmed in A-bomb survivors, although not ruled out. The doubling dose, that is, the dose that will double the natural incidence, is more than $1 \mathrm{~Sv}$ (National Research Council 1990). The recent UNSCEAR review gives an absolute risk of 3,000 to 4,7000 cases per gray per one million progeny. Thus, a 1-Gy exposure to a population has a risk corresponding to 0.4 to 0.6 percent of the baseline frequency of those disorders in the human population (UNSCEAR 2002).

Resources for heritable ill-health are increasingly appearing on the web. Many aspects of DOE's Human Genome Project http://www.ornl.gov/TechResources/Human_Genome/ are germane to high-dose radiation effects. For an introduction to genetics, see "Genetics 101" at http://www.ornl.gov/hgmis/project/info.html. For more in-depth information, see the DOE "Primer on Molecular Genetics" located at http://www.ornl.gov/TechResources/Human_Genome/publicat/primer/intro.html. 


\section{Conclusions}

Absorbed doses above1-2 Gy (100-200 rads) received over a period of a day or less lead to one or another of the acute radiation syndromes. These are the hematopoietic syndrome, the gastrointestinal (GI) syndrome, the cerebrovascular (CV) syndrome, the pulmonary syndrome, or the cutaneous syndrome. The dose that will kill about $50 \%$ of the exposed people within 60 days with minimal medical care, $L D_{50-60}$, is around $4.5 \mathrm{~Gy}$ ( $450 \mathrm{rads}$ ) of low- $L E T$ radiation measured free in air. The GI syndrome may not be fatal with supportive medical care and growth factors below about 10 Gy (1000 rads), but above this is likely to be fatal. Pulmonary and cutaneous syndromes may or may not be fatal, depending on many factors. The CV syndrome is invariably fatal.

Lower acute doses, or protracted doses delivered over days or weeks, may lead to many other health outcomes than death. These include loss of pregnancy, cataract, impaired fertility or temporary or permanent sterility, hair loss, skin ulceration, local tissue necrosis, developmental abnormalities including mental and growth retardation in persons irradiated as children or fetuses, radiation dermatitis, and other symptoms listed in Table 2 on page 10.

Children of parents irradiated prior to conception may experience heritable ill-health, that is, genetic changes from their parents. These effects are less strongly expressed than previously thought.

Populations irradiated to high doses at high dose rates have increased risk of cancer incidence and mortality, taken as about $10-20 \%$ incidence and perhaps $5-10 \%$ mortality per sievert of effective dose of any radiation or per gray of whole-body absorbed dose low-LET radiation. Cancer risks for non-uniform irradiation will be less.

Finally, there are many good references on the World Wide Web for treatment of radiation casualties that should be downloaded and printed in advance of any urgent need. An excellent single reference is the March, 2003, CDC "Acute Radiation Syndrome Fact Sheet for Physicians," available at http://www.cdc.gov/nceh/radiation/factsheets/AcuteRadSyndrome.pdf. 


\section{References}

Andrews GA. 1963. "Mexican Co-60 Radiation Accident." Isotopes and Radiation Technology 2(1):200-201.

Anno GH and RM Bloom. 2002. "Combined effects modeling of ionizing radiation and biological agent exposures." Military Medicine 167(2 Suppl):107-109.

Anno GH, RW Young, RM Bloom, and JR Mercier. 2003. "Dose response relationships for acute ionizing-radiation lethality." Health Physics 84(5):565-575.

Castle PE, M Garcia-Closas, T Franklin, S Chanock, V Puri, R Welch, N Rothman, and J Vaught. 2003. "Effects of electron-beam irradiation on buccal-cell DNA." American Journal of Human Genetics 73(3):646-651.

Committee on the Biological Effects of Ionizing Radiation (BEIR VI) NRC. 1998. Health Effects of Exposure to Radon: BEIR VI. National Academy Press, Washington, DC.

Cucinotta FA, FK Manuel, J Jones, G Iszard, J Murrey, B Djojonegro, and M Wear. 2001. "Space radiation and cataracts in astronauts." Radiation Research 156(5 Pt 1):460-466.

Eckerman KF, RW Leggett, CB Nelson, JS Puskin, and ACB Richardson. 1999. Health Risks From Low-Level Environmental Exposure to Radionuclides. Radionuclide-Specific Lifetime Radiogenic Cancer Risk Coefficients for the U.S. Population, Based on Age-Dependent Intake, Dosimetry, and Risk Models. Federal Guidance Report No. 13. EPA 402-R-99-001, United States Environmental Protection Agency, Washington, DC 20460.

Evans JS, S Abrahamson, MA Bender, BB Boecker, ES Gilbert, and BR Scott. 1993. Health Effects Models for Nuclear Power Plant Accident Consequence Analysis. Part I. Introduction, Integration, and Summary. NUREG/CR-4214 Rev. 2, Part I, Office of Nuclear Regulatory Research, Washington,D.C.

Evans JS, DW Moeller, and DW Cooper. 1985. Health Effects Model for Nuclear Power Plant Accident Consequence Analysis. Part 1: Introduction, Integration, and Summary. Part II: Scientific Basis for Health Effects Models. NUREG/CR-4214 AND SAND85-7185, Office of Nuclear Regulatory Research, Washington, DC.

Glasstone S and PJ Dolan. 1977. The Effects of Nuclear Weapons. United States Department of Defense and the Energy Research and Development Administration, Washington, DC.

Goossens LH and FT Harper. 1998. "Joint EC/USNRC expert judgement driven radiological protection uncertainty analysis." J.Radiol.Prot. 18(4):249-264.

Gottlober P, M Steinert, M Weiss, V Bebeshko, D Belyi, N Nadejina, FH Stefani, G Wagemaker, TM Fliedner, and RU Peter. 2001. "The outcome of local radiation injuries: 14 
years of follow-up after the Chernobyl accident." Radiation Research 155(3):409-416.

Hall EJ. 2000. Radiobiology for the Radiologist. Lippincott Williams \& Wilkins, Philadelphia, Pennsylvania.

Haskin FE, FT Harper, LH Goossens, BCP Kraan, JB Grupa, and J Randall. 1997a. Probabilistic Accident Consequence Uncertainty Analysis: Early Health Effects Uncertainty Assessment. Appendices. NUREG/CR-6545, EUR 15855 Vol. 2, U.S. Nuclear Regulatory Commission, Washington, DC.

Haskin FE, FT Harper, LH Goossens, BCP Kraan, JB Grupa, and J Randall. 1997b. Probabilistic Accident Consequence Uncertainty Analysis: Early Health Effects Uncertainty Assessment. Main Report. NUREG/CR-6545, EUR 15855 Vol. 1, U.S. Nuclear Regulatory Commission, Washington, DC.

Heidenreich WF, TI Bogdanova, P Jacob, AG Biryukov, and ND Tronko. 2000. "Age and time patterns in thyroid cancer after the Chernobyl accidents in the Ukraine." Radiation Research 154(6):731-732.

International Commission on Radiation Units and Measurements (ICRU). 1998. Fundamental Quantities and Units for Ionizing Radiation. ICRU Report No. 60, ICRU Publications, Bethesda, Maryland.

International Commission on Radiological Protection (ICRP). 1991. "1990 Recommendations of the International Commission on Radiological Protection. ICRP Publication No. 60." Annals of the ICRP 21(1-3).

International Commission on Radiological Protection (ICRP). 2000a. "Avoidance of Radiation Injuries from Medical Interventional Procedures. ICRP Publication No. 85." Annals of the ICRP $30(2)$.

International Commission on Radiological Protection (ICRP). 2000b. "Pregnancy and Medical Radiation. ICRP Publication No. 84." Annals of the ICRP 30(3).

International Commission on Radiological Protection (ICRP). 2002a. "Managing Patient Dose in Computed Tomography. ICRP Publication No. 87." Annals of the ICRP 30(4).

International Commission on Radiological Protection (ICRP). 2002b. "Prevention of Accidents to Patients Undergoing Radiation Therapy. ICRP Publication No. 86." Annals of the ICRP 30(3).

International Commission on Radiological Protection (ICRP). 2003. "Biological Effects after Prenatal Irradiation (Embryo and Fetus). ICRP Publication No. 90." Annals of the ICRP 33(1-2).

Jacob P, G Goulko, WF Heidenreich, IA Likhtarev, I Kairo, ND Tronko, TI Bogdanova, J Kenigsberg, E Buglova, V Drozdovitch, A Golovneva, EP Demidchik, MI Balonov, I Zvonova, and V Beral. 1998. "Thyroid Cancer Risk to Children Calculated." Nature 392(5 March 
1998):31-32.

Little M, C Muirhead, LH Goossens, FT Harper, BCP Kraan, RM Cooke, and SC Hora. 1997a. Probabilistic Accident Consequence Uncertainty Analysis: Late (Somatic) Health Effects Uncertainty Assessment. Appendices. NUREG/CR-6555, EUR 16774 Vol. 2, U.S. Nuclear Regulatory Commission, Washington, DC.

Little M, C Muirhead, LH Goossens, FT Harper, BCP Kraan, RM Cooke, and SC Hora. 1997b. Probabilistic Accident Consequence Uncertainty Analysis: Late (Somatic) Health Effects Uncertainty Assessment. Main Report. NUREG/CR-6555, EUR 16774 Vol. 1, U.S. Nuclear Regulatory Commission, Washington, DC.

Mettler FAJ and RD Moseley, Jr. 1985. Medical Effects of Ionizing Radiation. Grune \& Stratton, Inc., Orlando, Florida.

Military Medical Operations, Armed Forces Radiobiology Research Institute. 2003. Medical Management of Radiological Casualties. AFRRI Special Publication 03-1. Armed Forces Radiobiology Research Institute, Bethesda, Maryland.

National Council on Radiation Protection and Measurements (NCRP). 1980. Influence of Dose and Its Distribution in Time on Dose-Response Relationships for Low-LET Radiations. Report No. 64, NCRP Publications, Bethesda, Maryland.

National Council on Radiation Protection and Measurements (NCRP). 1985. Induction of Thyroid Cancer by Ionizing Radiation. NCRP Report No. 80, NCRP Publications, Bethesda, Maryland.

National Council on Radiation Protection and Measurements (NCRP). 1989. Guidance on Radiation Received in Space Activities. Report No. 98, NCRP Publications, Bethesda, Maryland.

National Council on Radiation Protection and Measurements (NCRP). 1997. Uncertainties in Fatal Cancer Risk Estimates Used in Radiation Protection. NCRP Report No. 126, NCRP, Bethesda, Maryland.

National Council on Radiation Protection and Measurements (NCRP). 2001a. Evaluation of the Linear-Nonthreshold Dose-Response Model for Ionizing Radiation. NCRP Report No. 136, NCRP, Bethesda, Maryland.

National Council on Radiation Protection and Measurements (NCRP). 2001b. Radiation Protection Guidance for Activities in Low Earth Orbit. NCRP Report No. 132, NCRP, Bethesda, Maryland.

National Council on Radiation Protection and Measurements (NCRP). 2002. Operational Radiation Safety Program for Astronauts in Low-Earth Orbit: A Basic Framework. NCRP Publications, Bethesda, Maryland. 
National Research Council. 1988. Health Risks of Radon and Other Internally Deposited Alpha Emitters (BEIR IV). National Academy Press, Washington, DC.

National Research Council. 1990. Health Effects of Exposure to Low Levels of Ionizing Radiation (BEIR V). National Academy Press, Washington, DC.

North Atlantic Treaty Organization. 1996. FM 8-9 NATO Handbook on the Medical Aspect of NBC Defensive Operations AMedP-6(B). http://www.vnh.org/MedAspNBCDef/toc.htm. NATO, Brussels.

Peter RU. 2002. "Management of Skin Injuries in Radiation Accidents: The Cutaneous Radiation Syndrome." in The Medical Basis for Radiation-Accident Preparedness. The Clinical Care of Victims, eds. RC Ricks, ME Berger, and FM O'Hara, pp. 225-229. The Parthenon Publishing Group, Boca Raton.

Peter RU, M Steinert, and P Gottlöber. 2002. "The cutaneous radiation syndrome: diagnosis and treatment." Radioprotection 36(4):451-457.

Preston DL, Y Shimizu, DA Pierce, A Suyama, and K Mabuchi. 2003. "Studies of mortality of atomic bomb survivors. Report 13: solid cancer and noncancer disease mortality: 1950-1997." Radiation Research 160(4):381-407.

Puskin JS and CB Nelson. 1994. Estimating Radiogenic Cancer Risks. EPA 402-R-93-076, U.S. Environmental Protection Agency, Washington, DC.

Puskin JS, CB Nelson, and DJ Pawel. 1999. Estimating Radiogenic Cancer Risks Addendum: Uncertainty Analysis. EPA 402-R-99-003, U.S. Environmental Protection Agency, Washington, DC.

Russell WL and EM Kelly. 1982. "Mutation Frequencies In Male Mice And The Estimation Of Genetic Hazards Of Radiation In Men." Proceedings of the National Academy of Sciences 79:542-544.

Thomas RE and DG Brown. 1961. "Response of Burros to Neutron-gamma-radiation." Health Physics 61(1):19-28.

U.S. Nuclear Regulatory Commission (NRC). 1989. Health Effects Models for Nuclear Power Plant Accident Consequence Analysis. Low LET Radiation. Part II: Scientific Bases for Health Effects ModelsSummary. NUREG/CR-4214 Rev. 1, Part II, Office of Nuclear Regulatory Research, Washington,D.C.

U.S. Nuclear Regulatory Commission (NRC). 1990. Health Effects Models for Nuclear Power Plant Accident Consequence Analysis. Low LET Radiation. Part I: Introduction, Integration, and Summary. NUREG/CR-4214 Rev. 1, Part I, Office of Nuclear Regulatory Research, Washington,D.C. 
U.S. Nuclear Regulatory Commission (NRC). 1991. Health Effects Models for Nuclear Power Plant Accident Consequence Analysis. Modifications of Models Resulting from Recent Reports on Health Effects of Ionizing Radiation. Low LET Radiation. Part II: Scientific Bases for Health Effects Models. NUREG/CR-4214 Rev. 1, Part II, Addendum 1, Office of Nuclear Regulatory Research, Washington,D.C.

U.S. Nuclear Regulatory Commission (NRC). 1993. Health Effects Models for Nuclear Power Plant Accident Consequence Analysis. Modifications of Models Resulting from Addition of Effects of Exposure to Alpha-Emitting Radionuclides. Part II: Scientific Bases for Health Effects Models. NUREG/CR-4214 Rev. 1, Part II, Addendum 2, Office of Nuclear Regulatory Research, Washington,D.C.

United Nations Scientific Committee on the Effects of Atomic Radiation (UNSCEAR). 1993. Sources and Effects of Ionizing Radiation: UNSCEAR 1993 Report to the General Assembly, with Scientific Annexes. United Nations Publications, Vienna, New York.

United Nations Scientific Committee on the Effects of Atomic Radiation (UNSCEAR). 1994. Sources and Effects of Ionizing Radiation: UNSCEAR 1994 Report to the General Assembly, with Scientific Annexes. United Nations, Vienna.

United Nations Scientific Committee on the Effects of Atomic Radiation (UNSCEAR). 2001. Sources and Effects of Ionizing Radiation: UNSCEAR 2000 Report to the General Assembly, with Scientific Annexes. Vol. II: Effects. United Nations, New York.

United Nations Scientific Committee on the Effects of Atomic Radiation (UNSCEAR). 2002. Hereditary Effects of Radiation: UNSCEAR 2001 Report to the General Assembly, with Scientific Annex. E.01.IX.2, United Nations, New York.

Walker RI, TJ Cerveny, LA Alt, V Bogo, RF Dons, NK Farzaneh, CD Forcino, LI Giambarresi, LW Luckett, TJ MacVittie, GA Mickley, BE Vesper, TL Walden Jr., BR West, and RW Young. 1989. Textbook of Military Medicine. Part I: Warfare, Weaponry, and the Casualty. Volume 2: Medical Consequences of Nuclear Warfare. http://www.afrri.usuhs.mil/www/outreach/pdf/tmm/. Armed Forces Radiobiology Research Institute, Bethesda, Maryland. 